\title{
WestVirginiaUniversity
}

THE RESEARCH REPOSITORY @ WVU

Graduate Theses, Dissertations, and Problem Reports

2006

\section{The mythical speech of Janine Antoni}

Patrick L. Jones

West Virginia University

Follow this and additional works at: https://researchrepository.wvu.edu/etd

\section{Recommended Citation}

Jones, Patrick L., "The mythical speech of Janine Antoni" (2006). Graduate Theses, Dissertations, and Problem Reports. 807.

https://researchrepository.wvu.edu/etd/807

This Thesis is protected by copyright and/or related rights. It has been brought to you by the The Research Repository @ WVU with permission from the rights-holder(s). You are free to use this Thesis in any way that is permitted by the copyright and related rights legislation that applies to your use. For other uses you must obtain permission from the rights-holder(s) directly, unless additional rights are indicated by a Creative Commons license in the record and/ or on the work itself. This Thesis has been accepted for inclusion in WVU Graduate Theses, Dissertations, and Problem Reports collection by an authorized administrator of The Research Repository @ WVU. For more information, please contact researchrepository@mail.wvu.edu. 


\title{
The Mythical Speech of Janine Antoni
}

\author{
Patrick L. Jones \\ Thesis submitted to the \\ College of Creative Arts \\ at West Virginia University \\ in partial fulfillment of the requirements \\ for the degree of
}

Master of Arts

in

Art History

Paul Krainak, M.F.A., Chair

Robert Hopson, Ph.D.

Kristina Olson, M.A.

Division of Art

\author{
Morgantown, West Virginia \\ 2006
}

Keywords: Janine Antoni, Roland Barthes, Feminism, Myth, Contemporary Art Copyright 2006 Patrick L. Jones 


\section{$\underline{\text { Abstract }}$ \\ The Mythical Speech of Janine Antoni \\ Patrick L. Jones}

The confrontation of societal myths has been a major concern of many female artists since the 1960s. However, confronting the ideological construction of myth is not enough to discredit it. The semiology of myth, according to Roland Barthes (1915-1980), simply absorbs this confrontation by placing the artist in the position of a signifier of the myth itself. Paradoxically, in order to discredit myth the artist must "speak the myth," in order to empty the ideological content of the myth through the adoption of mythical speech. This produces a counter-myth. Language as a vehicle of feminist expression has been a permeating issue central to $20^{\text {th }}$ century women artists. However, their voices have often been silenced through the semiological structure of myth, unable to "speak the myth.”

This paper addresses several works of art by Janine Antoni (b. 1964, Freeport, Bahamas) who is able to overcome the powerful semiological construction of myth through the use of mythical speech and the creation of the counter-myth. She does this through a pluralistic approach that often combines performance and the object, which historicizes the work of art, semiologically mythologizing the myth. In order to fully examine Antoni's approach, a comparative analysis is necessary to determine the nature of myth and its relationship to visual art. Therefore, this paper begins by discussing three postmodern female artists: Sherrie Levine (b. 1947), Cindy Sherman (b. 1954) and Marina Abramovic (b. 1946). This approach establishes historical precedents of feminist art of the $20^{\text {th }}$ century and attempts to reveal the various ways in which the semiological system of myth is able to distort the "speaker," through authorship and the body politic. 


\section{Contents}

Acknowledgements........................................................................................iv

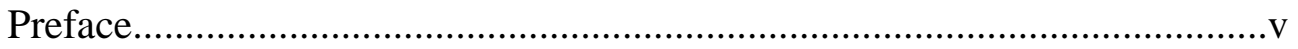

Introduction: Deconstructing the Text.............................................................vi

Chapter One: Sherrie Levine and the loss of "play”.......................................

Chapter Two: Cindy Sherman “overplaying” the Text.....................................6

Chapter Three: Marina Abramovic and the body politic..................................9

Chapter Four: Cindy Sherman's re-enforcement of the Author......................11

Chapter Five: Structuralist v. Post-structuralist myth......................................14

Chapter Six: And the myth absorbs Cindy Sherman.......................................19

Chapter Seven: Janine Antoni’s Gnaw......................................................24

Chapter Eight: Janine Antoni’s Lick and Lather.............................................36

Chapter Nine: Janine Antoni's Loving Care...................................................46

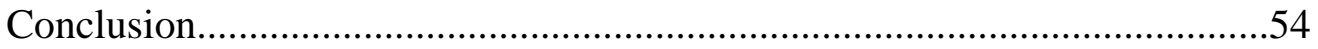

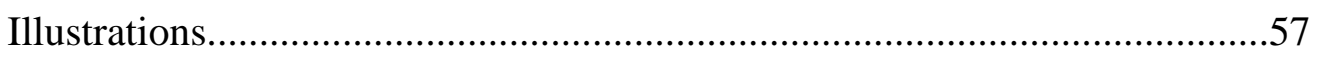

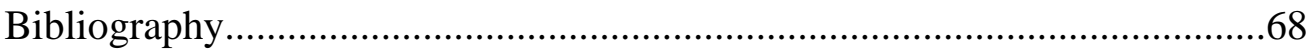




\section{$\underline{\text { Acknowledgements }}$}

I think that I should begin by thanking Misty Chinault Jones and Dorian Elizabeth Jones, my wife and daughter. Both of whom have sacrificed many hours away from me during the research, writing and editing of this paper. I would like to thank the efforts of my committee for their patience and commitment to the completion of this thesis. I would like to especially thank Kristina Olson who has supported this project from its inception through many consequent drafts and whose insight offered acute and extremely helpful comments and suggestions. Most of all, I would like to thank my mother, Patricia Blanche Jones (1943-2005), whose support and strength has always been my guiding star. This work is dedicated to her life and memory. 


\section{Preface}

"The fateful question for the human species seems to me to be whether and to what extent their cultural development will succeed in mastering the disturbances in their communal life by the human instinct of aggression and self-destruction." ${ }^{\text {- }}$ - Sigmund Freud

The work of New York based artist Janine Antoni (b. 1964) echoes this the last question posed by Sigmund Freud in Civilization and Its Discontents. Freed by the adoption of the postmodern deconstruction of the Text, Antoni often shifts aesthetic approaches and mediums in pursuit of her concerns. Antoni comments on these concerns by stating, "I feel attached to my artistic heritage and I want to destroy it."” However, this destructive impulse does not find fruition in the destruction of art but, rather, through a semiological construct that Roland Barthes refers to as counter-myth, Antoni inserts herself in this history transforming it into an interrogative that questions gender identity. Through a pluralistic approach that often combines performance and medium, Janine Antoni, abandoning the passive voice of the Text alone used by many appropriation artists of the early 1980s, embraces an active voice of mythic speech.

${ }^{1}$ Sigmund Freud, Civilization and Its Discontents , translation by James Strachey (New York: W. W. Norton \& Company, 1961), 92. 


\section{Introduction: Deconstructing the Text}

The modernist quest of originality and authorship no longer exists within today’s postmodern society. This critique may have originated as early as the 1960s with Pop art, and its inclusion of mass-media imagery. However, this critique surely found its fruition in the 1980s with the use of deconstruction, employed mainly in the form of appropriation. Appropriation artists went a step beyond Andy Warhol (1928-1987) and other Pop artists who simply referenced or crudely imitated mass media. ${ }^{3}$ Popular culture images, well-known art works, and even actual pristine commercial goods were often presented to a weary public without alteration. For example, Jeff Koons (b. 1955) became well known during the early 1980s for his Hoover Deluxe series, in which the artist merely presented the vacuum cleaners with Plexiglas and fluorescent lights. The artist's "touch,” which was the signature of the Abstract Expressionist, is completely removed through the re-presentation of the appropriated.

Furthermore, the geometric abstraction of the minimalists is supplanted by the representational re-presentation of the appropriated, and art movements, including minimalism, were also appropriated visually. The postmodern aesthetic is a scavenger, which feeds upon the carrion of Modernism and the past. The original aims of the appropriated artwork are supplanted by those of the postmodern artist, without prejudice. The methodology of appropriation can be viewed as reflective of contemporary French philosophical thinking, which centered on deconstructing the subject. Caroline Williams provides a satisfactory working definition of deconstruction, stating, “[d]econstruction

\footnotetext{
${ }^{2}$ RoseLee Goldberg, Performance: Live Art Since 1960 (New York: Harry N. Abrams,1998), 137.

${ }^{3}$ An obvious exception to this is Warhol's Brillo Boxes, which were quite indistinguishable from the crude originals. The Brillo box series could be easily seen as an antecedent of the appropriation artists of the 1980s, many of whom no doubt looked toward Warhol as an exemplar of the postmodern artist.
} 
may be best understood as an exploration, location and questioning of the conditions governing the possibility of conceptualization, together with a consideration of the historicity of meaning and modes of subjectivity which may support systems of thought." ${ }^{4}$ One may immediately recall the work of David Salle (b. 1952), Sherrie Levine (b. 1947), Barbara Kruger (b. 1945) and Cindy Sherman (b. 1954). Like Warhol, these artists provide no conclusions within their work, but provoke a questioning of their subjects.

Through the use of appropriated images and motifs, which provides an inherent repetition, the subject is eclipsed, or decentralized. This decentralization of the subject forces one to what the French deconstructivists, Jacques Derrida (1930-2004) and Roland Barthes (1915-1980) refer to as the Text. The Text, perhaps, can be best understood as everything that surrounds the subject. Derrida's most profound statement speaks of its inclusiveness; “There is nothing outside the Text." 5 The Text is not a thing, but rather an action. An act of questioning facilitated by the semiological structure of the thing. Be it a word upon a page or an image, the signifier leads to the signified, and both are contained by the sign. Although simplistic at first, this type of analysis is quickly overrun by the Text, which has no finite possibilities.

Without finitude the Text risks the status of mysticism. Western thought since Aristotle has focussed on deductive logic. Roland Barthes asserts that the Text is a methodological field. ${ }^{6}$ Rather than being a system of Aristotelian thought, which is

\footnotetext{
${ }^{4}$ Caroline Williams, Contemporary French Philosophy: Modernity and the Persistence of the Subject (New York: Atholone Press, 2001), 110.

5 Jacques Derrida, translated by G. C, Spivak, Of Grammatology (Baltimore: The Johns Hopkins University Press, 1976): 158. 1977): 157.

${ }^{6}$ Roland Barthes, translated by Stephen Heath, Image Music Text (New York: Hill and Wang,
} 
reductive, the methodology of the Text is inductive. The Text cannot be reduced. To do so is to falsely limit it. Quantification of the Text is an illusion, which attempts to maintain the authority of the state and those who disseminate knowledge and ideas. To objectify the Text is to limit and quantify it - to maintain social control. Barthes warns against objectification, when he states, "[t]he Text is not to be thought of as an object that can be computed. It would be futile to try to separate out materially works from texts.”’7

An analogy can be made between the Text and the body. Just as the Minimalist artists attempted to engage the body through the foreign geometry of abstraction, the Text engages the mind through language, which is also a fabrication. Thus, we can find a phenomenology of the mind through the "physicality" of language itself. Barthes describes this when he states, "the Text is a process of demonstration, speaks according to certain rules (or against certain rules); the work can be held in the hand, the text is held in language, only exists in the movement of a discourse (or rather, it is Text for the very reason that it knows itself as text); the Text is not the decomposition of the work, it is the imaginary tail of the Text; or again, the Text is only experienced in an activity of production.”8 It is important to note that the Text, according to Barthes, is "held in language.” Language is where the Text manifests. It is "held” here; however, it is not necessarily confined to language.

Certainly, there are aspects of the Text, which are ineffable, and although these aspects lack verbalization, language can merely retain fragments of the Text considering its infinitude. Perhaps, one can visualize this "movement of discourse” as an ephemeral

\footnotetext{
${ }^{7}$ Roland Barthes, 156.

${ }^{8}$ Ibid., 157.
} 
object. Imagine cupping both hands together under a running faucet. The water "held" by the hands is similar to the Text "held" in language. The moment the faucet is turned off and the hands parted the "activity of production" ceases, and the "experience" of the Text is terminated. However the Text remains and this activity enriches the work, rather than decomposing it. The next chapter will explore the approach of the conceptual artist, Sherrie Levine, and her attempt to "leave the water running." 


\section{Chapter One: Sherrie Levine and the loss of "play"}

The work of Sherrie Levine of the 1980s embraced this aspect of the text through her appropriated images. Re-photographing well-known photographs by white male modernists, like Edward Weston, Levine with her photograph Untitled (After Edward Weston), 1981 (Fig. 1) forced discussion away from the subject. The image was not augmented in any deliberate way. Weston's image of his son Neil was copied faithfully by Levine. Levine’s and Weston's photographs are identical to one another. Levine forms a doppelganger of Weston’s original photograph. Her work does not attempt to "pass” as the original. The title provides attribution of original authorship by stating the work is “After Edward Weston.” Levine’s photograph is the fearless doppelganger. Without disguise or affectation, Levine’s photograph asserts its “inauthenticity.” Such a work evades traditional criticism through its blatant, unapologetic plagiarism. Formal characteristics of the image presented were of no consequence, since she did not make those decisions. The subject of the photograph is de-centered. This left the formalism of Clement Greenberg (1909-1994) in the dust of the postmodern critique of originality and authorship. The viewer can only question why the image was presented to the viewer. Levine confronts both originality and authorship through plurality. Barthes writes, "The Text is plural. Which is not to simply say that it has several meanings, but that it accomplishes the very plural of meaning: an irreducible (and not merely the acceptable) plural.” Just as the Text is plural, so too is Levine’s object. The object of the photograph is not one of singularity, but one of plurality. Its plurality is limited to produce value. It

\footnotetext{
${ }^{9}$ Roland Barthes, Image Music Text, 159.
} 
too is not a medium of originality, but a medium of the copy. To place limits upon its duplication is to assert a social control upon the object and reflects society's need for authorship to place limits upon the Text. Barthes comments upon the use of authorship, when he explains, "[t]o give a text an Author is to impose a limit on that text, to furnish it with a final signified, to close the writing." ${ }^{\text {10 }}$ By imposing a limited singularity upon the photograph its authorship is reinforced, and through this reinforcement the Text is closed. The Text is closed via an explanation as Barthes relates by stating, "[t]he explanation of a work of art is always sought in the man or woman who produced it, as if it were always in the end, through the more or less transparent allegory of fiction, the voice of a single person, the author 'confiding' in us."11

The photograph produces a semiological paradox according to Roland Barthes. Levine through her reproduction of the Weston "original” makes apparent this paradox. The photographic message is a mechanical analogue, and as such it can be described as denotative, without a code. However, it too has qualities, which we may call connotative. Being connotative, the photographic message is one with a code, that is "an object worked up, selected, composed, constructed, treated according to various professional, aesthetic, or ideological norms[.]"12 Thus, it is with the connotative that artistic meaning is manifested from the denotative, the visual analogue. Roland Barthes succinctly explains this paradox, when he states, "[t]he photographic paradox would then be the coexistence of two messages, one without a code (this would be the photographic analogue) and the other with a code [this would be the 'art,' or the treatment, or the "writing," or the

\footnotetext{
${ }^{10}$ Ibid., 147.

${ }^{11}$ Roland Barthes, Image Music Text, 143.

12 Roland Barthes, translated by Richard Howard, The Responsibility of Forms: Critical Essays on Music, Art and Representation, (New York: Hill and Wang, 1985), 7.
} 
rhetoric of the photograph]; structurally, the paradox is not of course the collusion of a denoted message and a connotative message: this is the probably inevitable status of mass communication; the paradox is that the connoted (coded) message develops here from a message without a code."13

Sherrie Levine emphasizes this paradox of the photographic through her reproduction of the analogue, the denotative message. Furthermore, Levine pairs Barthes' paradox with one of her own making. She places emphasis upon the selection of the original photograph as subject. When Barthes speaks of selection as an attribute of the connotative, he no doubt is referring to the actual object photographed. Levine's object is the original photograph, which already denotes a subject. However, it would be odd to think that Levine has photographed the photograph as an object of selection, because it is not placed within the context of other objects, which would have reinforced its objecthood. Instead, she has photographed the subject of the original, which is paradoxically its object.

Levine places an emphasis, then, on the denotative qualities of Weston's original photographic message through the choice of the subject-object of the original. There is a temptation to "read" Levine’s photograph in terms of the artist's gender, which seems to inform her selection and its inherent connotative message, the code. Otherwise, the photograph lacks a code, and in lacking a code the work is without a message. To do so is to place authorship over the work itself, and provide a claim of authority, which would limit and close the Text. Ironically, this makes Levine’s photograph “tyrannically

\footnotetext{
${ }^{13}$ Ibid., 7-8.
} 
centered on the author, his [or her] person, [and] his [or her] tastes."14 However, the work being without the code becomes its “code.”

The work itself is, perhaps, intended to be without a "meaning." To have a singular meaning would be to close the Text. It is simply a commodity, and this was the artist's intent. Levine comments on her intention of commodification as the dominant “text,” when she states the following: "My works were never intended to be anything but commodities [.] The work is in a dialectical relationship to the notion of originality. Originality was always something that I was thinking about, but there's also the idea of ownership and property...what does it mean to own something, and, stranger still, what does it mean to own an image?”15 Through Levine’s proliferation of Weston's original photograph, repetition becomes a theme of the work, and through this idea of repetition, Levine shifts the viewer's attention away from the depiction and toward the art object's relationship with a capitalistic system, in which governments and systems of authority are established to protect property. Furthermore, the work demonstrates the continuous redefinition of “property” within the ever-expanding parameters of capitalism.

Through second hand repetition of the “original,” Levine’s work facilitates active participation with the Text by placing emphasis on the denotative aspect of the photographic message. Roland Barthes refers to this participation as "play.” This is not a reading or an interpretation of the "text", which would be consumptive, but a dualistic action. Barthes writes that “ '[p]laying’ must be taken here in all the polysemy of the term: the text itself 'plays' (like a door that 'plays' back and forth on its hinges; like a

\footnotetext{
${ }^{14}$ Roland Barthes, Image Music Text, 143.

15 Jeanne Siegel, “After Sherrie Levine,” Art Talk: The Early 80s, edited by Jeanne Siege(New York: Da Capo Press, 1990), 251.
} 
fishing rod in which there is some 'play'); and the reader plays twice over: he [or she] plays at the Text (ludic meaning), he [or she] seeks a practice which produces it; but so that this practice is not reduced to mimesis (the Text being exactly what reduces this reduction), he [or she] plays the Text [.]"16 Levine’s photograph "plays" with notions of originality, commodification and ownership within a capitalistic society.

The question that now dominates Levine's work is does her act of making or remaking constitute a mimesis of the works of others, reducing her own "play" with the Text. This is not to imply that her work does not employ postmodern concepts and ideas, but rather to question if her methods limit her own experience with the Text. The work itself is not a mimesis of the photograph, but rather, to use Jean Baudrillard's term, a simulation of the original, attesting to its hyperreality. ${ }^{17}$ Nevertheless, Levine's lack of process and, most importantly, the abstract singularity of the photograph reproduced diminish "play." If Levine’s work's lack of "play" diminishes the Text, then is "play” the solution, or can too much "play" be detrimental to the Text? In the following chapter, this notion of "overplaying" the Text will be explored through the work and approach of Cindy Sherman.

\footnotetext{
${ }^{16}$ Roland Barthes, translated by Richard Howard, The Rustle of Language, (New York: Hill and Wang, 1986): 62-63.

${ }^{17}$ Jean Baudrillard, “The Hyper-realism of Simulation,” Art in Theory 1900-1990: An Anthology of Changing Ideas, edited by Charles Harrison and Paul Wood (Maldin, MA: Blackwell Publishers Ltd), 1049-1051.
} 


\section{Chapter Two: Cindy Sherman "overplaying” the Text}

The inverse of this dilemma is seen in the photographic work of Cindy Sherman (Fig. 2). Beginning in the late 1970s, while still a graduate student, Sherman began inserting herself into her photographic compositions in an effort to combat stereotypical images of femininity produced by America’s mass-media culture and exploited by both Madison Avenue and Hollywood. With Untitled Film Still \#3 (Fig. 2), 1977, Sherman presents herself in a kitchen with its usual items: dish soap, pan, salt, etc. Within the asymmetrical compostition of this black and white photograph, Sherman's half-length body and portrait are awkwardly cropped. She appears to be ominously looking over her shoulder at someone or something beyond the picture format. This ambiguity provides theatricality to the image. The suspense created and the achromatic nature of the medium is reminiscent of a thriller by Alfred Hitchcock. Is Sherman an actress playing a role? Or is this a commentary on the "role,” or portrayal, of women in film. Although one may have the impression that this is a specific scene from a specific movie, Sherman's inspiration remains private, in order to widen the scope of criticism.

The construction of her photographic narratives may provide a disproportionate amount of the artist's “play,” which places emphasis on authorship and diminishes the Text. Sherman is best known for her self-portraits. However, within these photographs the artist attempts to remove the "self” from the portrait. The represented self is not her own, but rather one based upon prototypes of femininity. Sherman's involvement with the stereotypical guise of femininity (often undertaken), according to RoseLee Goldberg, is performance. Goldberg describes these early performances and their methodology, when she wrote the following: "Dressed up as a housewife or a clerk in an unemployment 
office (and one as a well-known art collector), she would pass unnoticed at museum openings or at her job as a receptionist in a downtown New York gallery. Later, she would photograph herself in various outfits in her small bedroom studio.”18

Unlike Levine, Sherman is a direct descendent of the female performance work of the 1960s and 1970s and its emphasis upon the role of the Body Politic. Many artists, such as Marina Abromavic, Yoko Ono and Carolee Scheemann, placed an overwhelming emphasis on their individual bodies as the conduit for meaning. This emphasis upon the physical body of the artist is not something new. Actually, such an emphasis can be traced back to Jackson Pollock and the objectives of the so-called Action Painters of the 1950s. Bodily engagement is made visible in these paintings through the application of the paint. Harold Rosenberg focused upon this performative aspect of Action painting, when he stated the following: "What matters is the revelation contained in the act [.] Since the painter (artist) has become an actor, the spectator has to think in a vocabulary of action: its concept, duration, direction—psychic state, concentration and relation of the will [.]"19 Finding such a connection between female performance work of the 1960s and 1970s with the work of the stereotypically macho action painters may seem incongruent at first. However, such a connection seems to exist. The role of the body is paramount in both. As Paul Schimmel aptly states from the following passage: “The move from an uncontrolled action of the wrist to the more dramatic sweep or gesture of the arm, which required the artist to move around canvas rolled out flat on the floor, altered both the

\footnotetext{
${ }^{18}$ RoseLee Goldberg with foreword by Laurie Anderson, Performance: Live Art Since 1960 (New York: Harry N. Abrams, Inc., 1998), 201.

${ }^{19}$ Harold Rosenberg, “The American Action Painters,” Art in Theory 1900-1990: An Anthology of Changing Ideas, Edited by Charles Harrison and Paul Wood (Cambridge, MA: Blackwell Publishers, 1993), 581-582.
} 
traditional concept of what a painting was and how one could be made. Pollock's activities portended the dissolution of the boundaries between the object and the activities of its making."20 If one thinks progressively, then it seems that Pollock's work questions the need of the object. Afterall, Pollock's process seems to override the importance of the object produced, making it merely a commodity. The next chapter will explore this notion of removing the object, central to performance art of the 1960s and 1970s, by focusing upon the performance-based process of Marina Abramovic (b. 1946) seen in a work entitled Rhythm O from 1974.

${ }^{20}$ Paul Schimmel, "Leap into the Void: Performance and the Object,” Out of Actions, Between Performance and the Object (New York: Thames and Hudson, 1998), 19. 


\section{Chapter Three: Marina Abramovic and the body politic}

The critical difference between female performance art of the 1960s and 1970s and action painting is not simply the removal of the object, but the active examination of the body politic. Susan Bordo clearly describes the body politic, when she states the following: "The body — what we eat, how we dress, the daily rituals through which we attend to the body is medium of culture. ${ }^{21}$ If the body is a medium of culture, then who determines the construct of the body? This is the question that dominated feminist performance art of the 1960s and 1970s. Many of these artists sought simply to expose the body politic through the performance. Marina Abramovic, for example, performed a work entitled Rhythm $O$ in 1974. In this work, the artist remained passive for six hours in a gallery in Naples, during which the viewers/participants were free to use any of the various instruments of pleasure or pain upon the artist without her resistance. Within this state of self-imposed vulnerability, the artist revealed the depravity and heroism of humankind. Her clothes were cut off with the provided razor blades. One man cut her face with a razor blade and like a vampire began sucking her blood. A protective group developed, and when the loaded revolver was thrust into her face, a fight broke out between the two groups of viewers/participants. ${ }^{22}$ Abramovic's passivity and vulnerability ignited a sociological spectacle examining the role of power.

Most interesting, the viewers/participants tolerated a great amount of degrading behavior and did not act until the artist's life was threatened. This demonstrates the status

${ }^{21}$ Susan Bordo, “The Body and the Reproduction of Feminity,” Writing on the Body: Female Embodiment and Feminist Theory, edited by Katie Conboy, et. al. (New York: Columbia University Press, 1997), 90.

${ }^{22}$ Thomas McEvilley, “Marina Abramovic/ Ulay Ulay/ Marina Abramovic,” Art Forum 13, no.1 (September:1983): 52. 
of the woman within Western culture. The female performance artist, like any female performer, exists for the pleasure of the audience, no matter the depravity, and only when mortality is placed in the forefront do others come to her aid. The behavior of the viewers/participants of Rhythm $O$ is not representative of anarchy; rather it represents the norms of the body politic and woman's diminished and relatively insignificant role. Woman exists for pleasure. Furthermore, the conditions of the performance constitute a silent speech on the artist's behalf, placing the viewers/participants into uncertain roles, which attempts to dislocate the body politic. Moira Gatens describes two strategies to silence those who dare to speak in a voice other than the one sanctioned by the body politic. She states, “The first is to "animalize” the speaker, and the second, to reduce her to her 'sex.",23 In Rhythm $O$ both strategies are demonstrated, the first action performed unto Abramovic is the removal of her clothing, which is an attempt to reduce her to her "sex." Such actions as the sucking of her blood "animalizes" the artist, making her the physical object of nourishment. Through passivity the artist reveals the strength of the body politic and the levels of depravity and sadism necessitated to protect it. Cindy Sherman's photographs are, by contrast, an attempt to "play” the body politic by rejecting passivity and “constructing” the identity. However, these “”'constructed” identities are not original creations by Sherman but, rather, products of the body politic. The following chapter attempts to determine whether Sherman's “play” is singular, or if it translates into "play” for the viewer of the work.

\footnotetext{
${ }^{23}$ Moira Gatens, “Corporeal Representation in/and the Body Politic,” Writing on the Body: Female Embodiment and Feminist Theory, edited by Katie Conboy, et. al. (New York: Columbia University Press, 1997), 84.
} 


\section{Chapter Four: Cindy Sherman's re-enforcement of the Text}

Cindy Sherman's private or discrete performances of identity rely upon both the body politic for subject and content. Sherman’s actions, however, do not challenge the norms and mores of the body politic. Instead, they simply seem to record them through the photographic medium. This makes clear that Sherman's engagement with the "text" through "play" is greater than the viewer's participation with the photographic record of her performance. Sherman “plays” the body politic. However, her "play” does not translate into a "play” for the viewer. Her stereotypical guises are selected by the artist, and it is through this selection that the artist "plays" with the body politic. The viewer, however, is excluded. Sherman does demonstrate the authority of the portrait within Western civilization, and in this sense the body politic is engaged in a fruitful way. Ernst Van Alphen explains the authority of the portrait within the Western canon by stating, "[t]hus, authority is not so much the object of portrayal, but its effect. It is the portrait which bestows authority on an individual self."24

The documentation of her work through the photographic medium is also not performed in the same manner as that of female performance artists of the late 1960s and 1970s. Not functioning as a detached tool, the often-large prints provide intent beyond documentation. The resulting image is carefully composed, and unlike Levine's photographs of known photographs, the aesthetics of the image can easily be analyzed through formalist methods. In referring to Sherman’s early work, Goldberg notes that the photographs had the shared aesthetics of '60s French films and Hollywood B-movies. ${ }^{25}$

\footnotetext{
${ }^{24}$ Ernst Van Alphen, “The Portrait’s Dispersal: Concepts of Representation and Subjectivity in Contemporary Portraiture,” Portraiture: Facing the subject, edited by Joanna Woodall (Manchester: Manchester University Press, 1997), 240.

${ }^{25}$ RoseLee Goldberg, 201.
} 
Thus, unlike Levine, whose formal concerns had been eliminated through her reproduction of the reproductions, Sherman's have been largely nullified by the aesthetic qualities of the photographic document of her performance. To approach the "text" of Sherman's work, authorship of the image and its circumstances must be considered. This is paradoxical to the aims of postmodern deconstruction, which avoids authorship. As previously stated, Roland Barthes described the author's relationship as tyrannical. ${ }^{26}$ And he goes on to write the following: "The author is nothing but one who writes, just as $I$ is nothing but the one who says I: language knows a 'subject,' not a 'person' [.] ${ }^{\text {,27 }}$ To spite the questioning of the historical portrayal of women in film, Sherman distances the Text, not in her performative acts, but in her documentation of them as art-objects, and her attachment to authorship.

Failing to employ the Text in its entirety does not discredit the artistic efforts of Sherman and Levine, but demonstrates the elasticity of myth. These artists were building a new vocabulary for artistic expression based not on Modernist fallacies of originality and authorship, but rather one based in epistemology. This intense questioning of “norms" and their representations fostered later artists' interests in postmodern strategies of embracing the Text. Christopher Reed in his assessment of the emerging art of the late 1980s poignantly states that it is "[n]o longer the modernism that sublimated social concerns in a rhetoric of spiritual abstraction, neither is it the equally abstract play of social signifiers that was celebrated by the postmodernists ten years earlier. One logical outcome of the move away from abstraction and toward specificity is autobiography."28

\footnotetext{
${ }^{26}$ Roland Barthes, The Rustle of Language, 50.

${ }^{27}$ Ibid., 51.

${ }^{28}$ Christopher Reed, "Postmodernism and the Art of Identity,” Concepts of Modern Art: From Fauvism to Postmodernism, edited by Nikos Stangos (New York: Thames and Hudson, 1997), 288.
} 
Although the autobiographical content of the newly developing works of the late 1980s and 1990s would seem to conflict with the postmodern death of the author, it does not simply due to its attachment to the art-object produced, which embodies the actions of the biography. Neither Levin nor Sherman engaged autobiography as a strategy for embracing the Text. To do so may have seemed an attachment to authorship and fixed identity that both artists were attempting to avoid. Paradoxically, autobiography has a potential to distort myth by injecting the individual into its history. To effectively employ autobiography in the work, the artist must resist structuralist notions of self, a series of absolutes, and engage post-structural modalities. The following chapter attempts to clarify the differences between structuralism and post-structuralism. 


\section{Chapter Five: Structuralist v. Post-structuralist myth}

An important artist to emerge in the 1990s whose complex work embraced identity as a defining characteristic was Janine Antoni (b.1964). She employed strategies of appropriation and performance without the conflicts of "play" experienced by Levine or the distancing of the Text experienced by Sherman. Unlike Levine’s and Sherman's well known works of the early 1980s that share an "abstract play of social signifiers" that Christopher Reed previously mentioned, Antoni’s work is attached to a “type” of biography, one of her actions and experiences during the production of her artworks. Her work engages the Text in an attempt "to name an identity and the mechanism of oppression that structures it."29

Antoni's work also rejects the passivity to the Text that was prevalent in the early 1980s, pursuing, instead, an active role in its formation. She does this through the creation of what Roland Barthes terms “myths.” His deconstruction of French "myths” during the 1950s led to his understanding of the semiological structure that supports ideology. Simply put: “Myth is a type of speech.”30 Myth, as Barthes uses the term, is a structure of ideology that has political meaning. A structure found within the language of expression. Barthes' poststructuralist form of myth is different from the structuralist one, which is best exemplified by the work of Claude Levi-Straus. Levi-Straus adheres to the binary structure of myth, which is to say that it is composed of opposites. A thing represented is good or bad, sacred or profane, positive or negative, and so on. Levi-Straus explains the use of binaries applied to myth, when he states, “[a] myth appears as a

\footnotetext{
${ }^{29}$ Christopher Reed, "Postmodernism and the Art of Identity,” 288.

${ }^{30}$ Roland Barthes, Mythologies (New York: Hill and Wang, 1972), 109.
} 
system of equations in which the symbols, never clearly perceived, are approximated by means of concrete values chosen to produce the illusion that the underlying equations are solvable.”31 Levi-Straus’ description exemplifies his use of binaries to describe the universality of myth, including those, which are not Western and may not be based upon binary codes. Nevertheless, this structure is imposed to quantify myth, and in doing so the Text of the myth is limited. Levi-Straus places a philosophical positivism upon myth to define, and limit, its language.

Thus, it may seem illogical to conflate myth and the Text, if one accepts that myth is based upon codes, which, in a way, deceive the reader. No doubt within Western culture myth has been a tool of politics, no matter its form. Myth historically has performed a necessary societal function. Levi-Straus explains this function as being a way to ease anxiety, stating the following: "A solution that is not a real solution to a specific problem is a way of relieving intellectual uneasiness and even existential anxiety when an anomaly, contradiction, or scandal is presented as the manifestation of a structure of order that can be perceived more clearly in aspects of reality that are less disturbing to the mind and the emotions."32

Taking Levi-Straus’ description into account, it comes not as a surprise that Barthes finds myth in opposition to the Text. This opposition takes the form of authorship. Barthes describes this conflict, when he states, "we know that to give writing its future, it is necessary to overthrow the myth: the birth of the reader must be at the cost of the death of the Author." ${ }^{\text {33 }}$ The false solution that myth in its traditional context

\footnotetext{
${ }^{31}$ Claude Levi-Straus, The Jealous Potter (Chicago: University of Chicago Press, 1996), 172.

32 Ibid., 171.

33 Barthes, Image Music Text, 148.
} 
provides is one that relinquishes authority to the Author. The Author may not simply be an individual within a society, but may be the society itself, the state. Myth within its traditional context imposes meaning upon the representation of all things, which threaten the intellectual and existential reality of the world view, and it is in this way that myth strangles the Text, in order to preserve, maintain and dictate societal norms and mores. What makes Antoni's use of “myth” quintessentially postmodern is a questioning of societal norms and expectations for femininity and her use of art historical precedents, both visually and conceptually to convey these ideas with the subtlety of "language."

If myth suppresses the Text through its authorship, then how is it possible for Antoni's work to successfully conflate the two, without negating both? Conflation does not necessarily bring about negation. The very idea that this would occur demonstrates the prevalence of binary thought even today, in an age of the postmodern. Through the juxtaposition of the Text and the structure of myth, Antoni is able to achieve a plurality through her absence, which may be read as a refusal of Authorship. A refusal of Authorship in turn is a refusal of society's myths. Thus, a paradox is created. Barthes actually supports the destruction of myth through mythmaking. A process, which at seems at first to be hypocritical, but with further reflection it is simply paradoxical. Because myth is so resilient, Barthes suggests that the only means to combat it is by forming a counter myth. Barthes states, "[t]ruth to tell, the best weapon against myth is perhaps to mythify it in its turn, and to produce an artificial myth: and this reconstituted myth will in fact be a mythology.,34

\footnotetext{
${ }^{34}$ Roland Barthes, "Myth Today," reprinted in A Barthes Reader, Susan Sontag, editor (Hill and Wang, 1982),123.
} 
Perhaps, an examination of myth in both the structuralist and post-structuralist forms is necessary to further explore the possibility of such a conflation of myth and Text. The structuralist form of Levi-Straus views myth as a series of incomplete codes from various sources within the society to create the myth. In regard to this, Levi-Straus states the following: "Imagine a text (the physical form of writing), difficult to understand in one language, translated into several languages; the combined meaning of all the different versions may prove richer and more profound than the partial, mutilated meaning drawn from each individual.”35 Levi-Straus, then, views myth as pluralistic, in that it draws from many sources. Barthes, however, would disagree. Within Barthes view this multiplicity of codes simply reduces the source of the myth to a singularity, which is palpable. The authority of a myth is placed with the author who is presented as possessing an omnipotence and omniscience.

Barthes view is metalinguistic and much more complex than the structuralist view, which reduces myth into a complex series of binary codes. The post-structuralist view of myth is a semiological system in which myth is manifested through a secondorder system that feeds off the first system. Barthes explains this, when he states, "[b]ut myth is a peculiar system, in that it is constructed from a semiological chain which existed before it: it is a second-order semiological system. That which is a sign (namely the associative total of a concept and an image) in the first system, becomes a mere signifier in the second.”36 The second-order system of post-structuralist myth is precisely why any avoidance of authorship is thwarted. Cindy Sherman attempts to disrupt

\footnotetext{
${ }^{35}$ Claude Levi-Straus, 171.

${ }^{36}$ Roland Barthes, “Mythology Today,” reprinted in A Barthes Reader, Susan Sontag, editor (Hill and Wang, 1982),99.
} 
authorship and identity by portraying herself in multiple guises. However, the secondorder system places her actual identity in the position of signifier for the myth. The following chapter discusses how myth creates the Author, in order to place Sherman, the actual person, into the position of second-order signification, thus distorting her content and preserving the body politic. 


\section{Chapter Six: And the myth absorbs Cindy Sherman}

Returning to the work of Cindy Sherman, it is possible to see both the resilience and essential structure found within the post-structuralist view of myth, which makes it so formidable. In many of her self-portraits, Sherman takes on the guise of a stereotype of femininity. With Untitled Film Still \#3 (Fig. 2), 1977, Sherman associates the female body with domesticity by placing herself in the setting of a kitchen. The viewer assumes to have just been interrupted by something or someone beyond the frame. She appears wide-eyed and frightened by that beyond the frame. Furthermore, she seems defenseless as though she is careful not to be seen by the other. Within this constructed photograph, the image of Sherman appears helpless and vulnerable. By inserting herself within the myth of the stereotype of helplessness and vulnerability, Sherman attempts to destabilize it. However, it can be argued that she is absorbed by the myth through this second-order signification. Rather than adding herself onto the semiological chain to create her own myth, the opposite seems to occur; the chosen myth of stereotyped femininity places her portrait in the first-order semiological position and continues the semiological chain from that point, and in a sense Sherman's actual identity is supplanted by the Author, which represses the Text.

Sherman's attempt to reveal the myths of femininity as false is countered by the very structure under attack. The second-order system of myth enables the myth to respond in a flexible way, shifting order at will. Sherman’s actual identity being presented is paramount to exposing the myth. However, by placing her identity into the first position of the semiological chain, the myth simply absorbs her identity into the role of mere signifier for the myth itself. Sherman's actual identity is emptied and replaced 
with the guise of the Author. A myth cannot be exposed; it is transparent in a sense. It is in many ways the societal norm. Barthes describes the difficulty of revealing the falsehood of myth, when he states, "[i]t thus appears that it is extremely difficult to vanquish myth from the inside: for the very effort one makes to escape its stranglehold becomes in its turn the prey of myth: myth can always, as last resort, signify the resistance which is brought to bear against it. ${ }^{37}$ Thus, Sherman is reduced to Authorship, and her actual identity within the stereotypical image becomes a novelty, which serves as a signifier of the myth, and not the signified. Rather than being a critique of the myth of women as helpless and vulnerable, the image (Fig. 2) represents the inverse due to Authorship. The image of Sherman affirms, or signifies, the myth here, and Sherman, the person, becomes an object as well, signifying a radical, a fringe element (a thing), to be tolerated but dismissed in a democratic society. This is a means on the part of myth to discredit the Author, in order to uphold the myth.

Myth as an semiological structure is, therefore, consumptive of all attacks waged upon it. To simply identify the myth to be questioned is to empower that very myth, with all criticism simply absorbed and reflected backed to the casual reader in the form of a signifier, which reaffirms the myth. This does not mean that myth is beyond reproach. On the contrary, myth is subject to its own system of secondary signification. Barthes explains, "[a]ll that is needed is to use it (myth) as the departure point for a third semiological chain, to take its signification as the first term of the second myth." ${ }^{\text {38 }}$ This

\footnotetext{
${ }^{37}$ Roland Barthes, “Mythology Today,” reprinted in A Barthes Reader, Susan Sontag, editor (Hill and Wang, 1982), 123.

${ }^{38}$ Roland Barthes, Mythologies (New York, New York: Hill and Wang, 1972), 135.
} 
production of a newly formed, reconstituted myth seems to have been the objective of both Levine and Sherman; however, the original myth was not countered simply because it was directly confronted by the artists. Neither was able to escape the semiological position of the Author. The myth confronted is not diminished, but instead embellished as myth reduces both artists to their sex. Authorship becomes a signifier for the myth itself. Sherman's and Levine's actual identities as living persons are emptied by the myth. What emerges from their work is not a "text" of feminism, but rather a myth in the guise of a "text." The reduction to Authorship closes the Text and signifies the myth. .

The problem of mythology is indeed quite complex. However, the possibility of a "counter-myth" is not a hypothetical solution to the problem of myth on the part of Barthes. It simply requires the paradoxical approach of mythologizing the myth. The language itself, "mythologizing myth," seems to be a rhetorical affirmation of the myth to be challenged. However, this is not true. On the contrary, by utilizing myth as a signifier, the role of the Author does not eclipse the criticism by forming a myth in the guise of a “text.” Instead, Authorship (sex) becomes an actual “text,” not closed, but open to the plurality of the Text.

The problem for the artist attempting to discredit a myth is the distortion of Authorship, no matter one's gender, race, ethnicity, age or place of national origin. If myth is confronted, that person is reduced to the signifier of the myth in the form of a "text," which is a self-affirming guise of the myth. Myth is a deformity. It simply distorts the person into the role of the signifier. This seems to be amplified with women artists. The body politic defends myth, and as previously mentioned when analyzing Abramovic's performance entitled Rhythm $O$ from 1974, the female artist is reduced to 
her "sex." ${ }^{39}$ By reducing the female artist to her "sex," the body politic objectifies the person. This objectification allows myth to reduce identity. This reduction of identity through objectification, in turn, permits myth to distort the person into the Author, closing the Text through a "text," which is really the original myth. Authorship paradoxically discredits the female artist, limiting her identity to a stereotype, which signifies the "radical," the "dismissive," the "hysterical," reaffirming the myth. In order to counter myth, one must engage it from the side and with ambiguity and a conceptual anonymity. Inserting oneself into the myth or relying on Authorship as a means of discrediting myth at best creates an anomaly.

Myth simplifies and makes reality digestible to the casual reader. Myth is a semiological system of empty signifiers and a sign, which is full: the myth. By directly encountering myth through gender and identity, the desired relationship is inverted by the myth, forcing a passivity of the signifier upon the artist. For example, Sherman places her own, real identity as a counterpoint to various myths of femininity, taking on various disguises, but the end result is that her actual identity is reduced to an empty signifier of the myth. Her identity is semiologically reduced to Authorship, which closes the Text. This occurs through confusion on the part of the artist. Ideology is confused with semiological reality. ${ }^{40}$ Barthes explains by stating that "[l]anguage is a form, it cannot be realistic or unrealistic. All it can do is be either mythical, or not, or perhaps...countermythical., ${ }^{41}$

To avoid Authorship, which is tyrannical to the Text, one must not confront myth. However, this seems to conflict with artistic strategies that attempt to expose the

\footnotetext{
${ }^{39}$ Moira Gatens, 84.

${ }^{40}$ Barthes, Mythologies, 136.
} 
falsehood of myth. To mythologize in return, to deform the myth, seems to accept the falsehoods that it represents. However, this thinking is ideological, not semiological. The gender of the artist must be ambiguous, and through this ambiguity, the myth is unable to deform, but must be deformed in return. Perhaps, one may initially be inspired to find representational androgyny as a feasible solution. However, myth functions with binaries. It simplifies. An androgynous image or maker would simply be given a sexual identity through Authorship or context. The image or maker would be subjugated into the role of male or female, and thus, the myth would distort the image or maker into the position of a signifier of the myth. Since myth seems born of binaries, the maker of the counter-myth must simultaneously be both known and anonymous. Identity must not become fixed in its representation. In the next chapter, the issue of how rigidity of identity can be avoided will be explored through the examination of Janine Antoni’s 1992 composite work, Gnaw: Chocolate Gnaw (Fig. 3), Lard Gnaw (Fig. 4) and Lipslick/ Phenylethylamine Display (Fig. 5).

${ }^{41}$ Barthes, Mythologies, 136. 


\section{Chapter Seven: Janine Antoni’s Gnaw}

Janine Antoni, like many contemporary artists, employs a pluralistic approach to her art making, which avoids a fixed artistic representation of individual identity. She does not restrict artistic efforts by either medium or process. Her work ranges from performance to photography. However, her most intriguing work, which has been referred to as “interperformance,” ${ }^{42}$ encompasses both the performative aspect of Cindy Sherman and the direct appropriation of Sherrie Levine, without distancing the viewer from the "text," or diminishing "play” through a singularity of appropriation.

Furthermore, by directly involving herself, bodily, in the manifested object, Antoni provides the performance-based art object, not with authorship, as seen in Sherman's photographs, but rather with a history of her actions.

Antoni’s 1992 New York solo debut featured a three-part performance-based art object entitled Chocolate Gnaw (Fig. 3), Lard Gnaw (Fig. 4), and Lipslick/ Phenylethylamine Display (Fig. 5). These are interrelated works that may be viewed individually or collectively. Both medium and action are quintessential to the work. Chocolate Gnaw began as a 600lb cube of chocolate in which the artist "eroded” through the compulsively repetitive action of biting and spitting out the portion acquired from the bite. With Lard Gnaw, Antoni began with a 600lb cube of lard and repeated the same laborious process of biting and spitting. Both works were presented raised above the floor of the gallery on slightly elevated, makeshift pedestals. The third part of the work, Lipslick/ Phenylethylamine Display, represents the "product” of Antoni’s efforts. The remnants of Antoni’s actions, the “regurgitated” lard and chocolate, were fashioned into

\footnotetext{
42 Jennifer Fisher, “Interperformance: The Live Tableau of Suzanne Lacy, Janine Antoni and Marina Abramovic,” Art Journal 56 (Winter 1997), 28.
} 
commercial goods associated with femininity and "professionally" placed within a commercial display case. The "regurgitated" chocolate was used to create chocolate hearts, and the lard was used to create lipsticks, which the artist's named "lipslicks".

All three parts are interconnected, with Antoni inserted into the role of primary signifier. The aesthetic structure of both Chocolate and Lard Gnaw is minimalist. The 600lb cubes recall works such as Die, 1962, by Tony Smith (Fig. 6), not simply by the cubic shape but also by its sheer massiveness. Both Lard Gnaw and Chocolate Gnaw may mimic the geometric reductive features of minimalist art, but the form is eroded by Antoni's physical involvement. She gnaws, bites and regurgitates the lard and chocolate to form the third part of the installation, the Lipslick Phenylethylamine Display, which contains 300 "lipslicks" made from the lard, and 34 heart shaped packages made from the chocolate. The historical allusion to minimalist art and its fundamental form was clearly used for phenomenological effect; however, the transcendental universal experience is nullified. According to Simon Taylor, "Antoni uses the artificiality of the cube to redirect attention to the body and its inchoate biological imperatives." ${ }^{43}$

By placing an emphasis on the phenomenological aspects of a work of art like Gnaw, Antoni is able to redirect attention of the viewer to the body of the maker. However, most conspicuously, the body of the maker, Antoni's body, is absent from the work. Dan Cameron makes note of this absence, when he states the following: "What is missing from the frame, but apparent from the relationship between the work's four components, is the role of the artist as a key performative element that has been conspiciously added and then removed. Of course this is true in any example of the

${ }^{43}$ Simon Taylor, “Janine Antoni,” Art in America 80 (October 1992), 149. 
plastic arts, but explicit references to Antoni's own physical interaction with the materials in Gnaw produces a structural tension that seems almost narrative in its complicity with

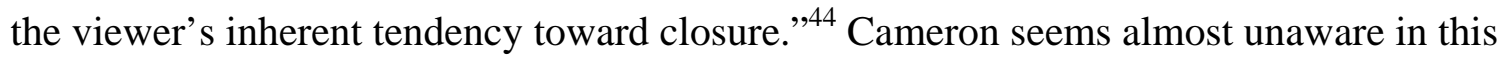
statement that this closure that he describes as a "tendency toward closure" is in effect a socially reinforced compulsive need for authorship. If such authorship could be applied to Antoni, as with Levine and Sherman, it would discredit Antoni and her "message" through "otherness," making her "radical" and therefore, dismissive. If one dismisses the work of Antoni as the "other," then the body politic is protected and the myths that draw their content from the body politic are thus reinforced.

This absence is fundamental to Gnaw. Initially, one may experience a feeling of invasion, as though vermin have nibbled feverishly upon a food substance left out in one's kitchen. The marks made by Antoni's teeth and mouth are initially left relatively unnoticed by the viewer, and then when discovered, seem to be invasive. The materiality of the substances, however, dislocates this feeling. Her activities seem then to represent overindulgence, an activity that is familiar to the viewers of Antoni’s work. (Afterall, how many of us have not at one time or another absent mindedly eaten an entire bag of potato chips or cookies.) The viewer can easily visualize the actions of Antoni conceptually, placing his or herself into the role of the artist. Thus, the making of Gnaw becomes a plural event conceptually. This plurality of the conceptual engagement of the activity, not only decreases Authorship, but it also opens the Text. Unlike a traditional performance which is inherently a part of time, the absence of the artist's body serves as a "place" to reengage the work, perpetuating it in time without diminishing the artist's

${ }^{44}$ Dan Cameron, “Parts and Whole: Three Works by Janine Antoni,” in Janine Antoni (New York, NY: Ink Tree Press, 2000), 31. 
actions. This conceptualism on the part of the viewer/participant increases the physical involvement with the work, increasing the phenomenological experience.

With Antoni's absence, the "completion" of the work can only be arrived at through the conceptual participation of the viewer/participant. The movement of the viewer/participant from one object to the other forces a sort of completion upon the viewer/participant, in which Antoni’s absence serves as an important part of the work, because it is the point of entry for the viewer to become the participant. The temporal aspect of participation through both physical movement and conceptual reenactment emphasizes the phenomenological qualities of Gnaw. Edmond Husserl refers to this activity, when he describes the temporal succession of phases, which create a conceptual form. He writes that "[t]he temporal succession itself as a form of being of the temporal object; the being of the temporal object is a being in succession of "object-points," which form a continuum by virtue of this continual form of being. ${ }^{\text {} 45}$ This continuum permits Gnaw to "exist" outside of the boundaries of time, endowing it with a sort of invisible form, which engages the viewer, forcing a conceptual participation that continues the activity of gnawing the lard and chocolate.

Cameron also makes note of this conceptual continuation of the activity, when he states that "[i]n effect, there are two Gnaws under consideration: one that is visible, and one in which the now-absent figure of the artist performed- and, in our imagination, continues to perform- the activities that resulted in the objects that we are now contemplating. ${ }^{46}$ Cameron seems, however, to be attempting to close the "text" of the

\footnotetext{
${ }^{45}$ Edmond Husserl, trans. John Barnett Brough, On The Phenomenology of the Consciousness of Internal Time (1893-1917) (Norwell, MA: Kluwer Academic Publishers, 1991), 271.

${ }^{46}$ Dan Cameron, "Parts and Whole: Three Works by Janine Antoni,” in Janine Antoni (New York, NY: Ink Tree Press, 2000), 31.
} 
activity and impose an imaginary authorship upon Antoni. Otherwise, why else would he insist the viewer imagine the artist continuing to perform the already performed actions? This reinforces an expectation of "otherness" in regard to the work, a conceptual distance rather than a conceptual engagement. Furthermore, it forces a singularity upon the artist as maker, which is ironic considering that he admits that the viewer must conceptualize, or “imagine," this activity. Cameron presupposes an open interaction with the work and then closes it with authorship. In doing so he neglects the historicism that Antoni implanted in the work by choosing the minimalist cube as the "visible form" of the work. This allusion was not anecdotical, but functional. A "linguistic" device utilized to redirect attention to the viewer and his or her physical body, rather than upon the artist, to do so would submit to the modernist notion of the artist as unique and singular, a "genius," which can be reduced to authorship.

Antoni's absence in the work also emphasizes the banality of the activity of eating, chewing and gnawing. These are activities that we all participate in on a daily basis for survival, and those that are ongoing typically without and conscious involvement. Amparo Lozano also makes note of this importance of absence, stating, “Janine Antoni conceives her work as an ongoing process, like those of everyday activities which make up our existence. In this way she converts those different everyday experiences -chewing, eating, washing, sleeping- into sculptural process.” ${ }^{47}$ Perhaps, the question that becomes most pervasive is what is the importance of emphasizing these activities? The answer is quite simplistic. The ideas that shape our lives are not the monumental questions of life, but instead they are truly the routines of everyday life that

\footnotetext{
${ }^{47}$ Amparo Lozano, "Presence and absence in a cyclical story by proximity,” Janine Antoni (Bacelona: La Fundacio “la Caixa,” 1996), 28.
} 
shape our identities. However, routines are only seemingly routine, particularly those that engage the public. These routines are not without regulation. On the contrary, they are extremely regulated and ordered. Even private activities have the potential for embarrassment and reprimand. How one eats, chews even swallows food is scrutinized. Even the selection of what one eats seems to inform others about our character. Thus, these activities are very much issues of morality. These banal everyday, almost dismissive activities create a semiological construct of identity. The value judgements that we experience are a result of the Body Politic that is perpetuated by myth. Susan Bordo explains this quite simply, when she states that "[t]he body---what we eat, how we dress, the daily rituals through which attend to the body---is a medium of culture."48 The question then evolves to whose culture? To the disenfranchised, such as women, the imposition of culture is often a tool of oppression.

Many scholars have scrutinized the body's role as a social construct. Perhaps, the most renowned is Michel Foucault who explored the body's role for societal control in his "genealogical” works such as Discipline and Punish and The History of Sexuality. In his text Discipline and Punish, Foucault describes what he calls the "docile body," one in which one's conscious political, social and personal beliefs are usurped by one's body. ${ }^{49}$ The everyday activities speak one's beliefs and ideologies, let alone social position within a culture. Bordo explains the significance of the “docile body' as it relates to feminism, when she states, "female bodies have become docile bodies---bodies whose forces and energies are habituated to external regulation, subjection, transformation,

${ }^{48}$ Susan Bordo, "The Body and the Reproduction of Feminity,” Writing on the Body: Female Embodiment and Feminist Theory, Conboy, Medina and Stanbury, ed.s (New York: Columbia University Press, 1997), 90.

${ }^{49}$ Michel Foucault, Discipline and Punish (New York: Vintage, 1979), 135-169. 
“improvement." ${ }^{\text {50 }}$ Antoni’s absent action of gnawing, not only creates a

phenomenological form, but also places emphasis on the role of such routine behaviors as eating, and how it is regulated by society in a way in which social control is hardly felt, but cumulative in its repercussions.

Through her actions, Antoni places herself (her body) into the position of the language-object, which 'speaks things. ${ }^{51}$ Myth is composed of metalanguage, which speaks of things. This is how myth is entrapping. When one comments on the structure of culture, one takes the position of the "other" and speaks about or of the myth itself. Antoni speaks the myth by placing herself (body) into the position of the language-object. Barthes explains this distinction quite clearly, when he describes the woodcutter scenario.

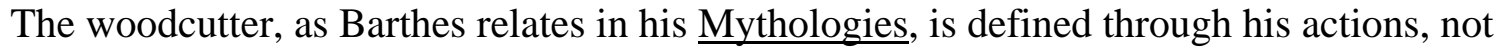
through discourse or reflection of those actions. To do so would be to mythologize the activity, and in the moment of those actions a language-object exists. The woodcutter 'speaks the tree. ${ }^{52}$ He does not speak 'about' or 'of' the tree. His relationship to the tree is operation. According to Barthes, "[t]his means that my language is operational, transitively linked to its object; between the tree and myself, there is nothing but my labour, that is to say, an action. This is a political language: it represents nature for me only inasmuch as I am going to transform it, it is language thanks to which I 'act the object'; the tree is not an image for me, it is simply the meaning of action., ${ }^{, 53}$

Antoni literally 'acts the object', when she gnaws and regurgitates the chocolate and lard cubes. Her actions can then be viewed as linguistic. Furthermore, the viewer's

\footnotetext{
${ }^{50}$ Bordo, 91.

${ }^{51}$ Barthes, Mythologies, 144.

52 Ibid., 145.

53 Barthes, Mythologies, 145-146.
} 
conceptual continuation of her action allows him or her to 'act the object' and not merely speak of or about the action, which pictorialism would encourage. The viewer 'speaks' the chocolate and the lard through this conceptual reenactment and continuation of the action. This removes any possibility of Authorship through the plurality of the viewer/participant. The Body Politic also loses its authority with Antoni’s absence, due to the inability to place Authorship, in which she would be reduced to her sex, which would perpetuate myths of femininity by animalizing the speaker (Antoni).

Unlike Marina Abramovic who was literally reduced to her sex and animalized by her viewer/ participants in her Rhythm O, Janine Antoni avoids this partly through her absence and by 'speaking' the activity of eating, but she is also successful due to the chosen materials. The substances that Antoni chose to gnaw and regurgitate in Lard Gnaw and Chocolate Gnaw encourage and engage the viewer to become the conceptual participant. If the substances had been unknown or offensive, then it would have been difficult to imagine the phenomenological form that resulted from her absence and the viewer/participation that occurred. Chocolate and lard, however, are familiar substances, which seem to appeal to the viewer due to their taboo qualities in a health conscious society. It is ironic that the first impulse is not to animalize Antoni, but to emulate her. Her action of gnawing at the two substances is an animalistic action. There is no pretence of table etiquette, but quite the contrary, an animalistic desire to engage the materials. An animalism that seems to appeal to the viewer, and his or her hidden, suppressed desires, and it is this identification of suppression of the personal, the animalistic, that exposes, in reflection, the body politic and the myths that control society, subjugating the disenfranchised. 
The focus on medium also makes reference to the post-minimalist process artists, such as Richard Serra (b. 1939), Hans Haacke (b. 1936), Joseph Beuys (1921-1986), and perhaps most importantly, Eva Hesse (1936-1970). Roberta Smith succinctly describes the movement being anti-form, or resistant to notions of permanence. According to Smith, many of these artists "held on to materials but jettisoned the object, divesting their work of structure, permanence and boundaries via random, temporary distributions, 'scatter pieces' both indoors and out, of no-rigid ephemeral substances- sawdust, cut-up bits of felt, loose pigment, flour, latex, snow, even cornflakes." ${ }^{54}$ Hans Haacke and Eva Hesse both often retained the Minimalist geometry, while placing emphasis on the medium to signify meaning. Antoni is no different. However, unlike the process artists whose innovative use of medium signified originality, Antoni's use of medium serves the task of signifying meaning, not only by means of its materiality, but also through the performative and mechanized processes that deconstruct it (Lard Gnaw and Chocolate Gnaw) and reconstruct it (Lipslick/ Polythylamine Display).

This reconstruction of the medium into the "Liplislicks" is repetitive of Antoni’s physical approach to her art making, and provides a dualistic mythological process. The making of Lard Gnaw and Chocolate Gnaw both take on historical precedents, and the "gnawing" too inserts Antoni into the physical history of the objects. The latter Lipslick/ Polythylamine Display becomes externalized, through its mechanical reproduction, as a deformation of Antoni's internal deformation of "myth.” Through her own appropriation of art historical signifiers Antoni deforms their independent meanings, which were full of signification independently and empties them through her action of gnawing and

\footnotetext{
${ }^{54}$ Roberta Smith, "Conceptual Art," in Concepts of Modern Art: From Fauvism to Postmodernism, edited by Nikos Stangos (New York: Thames and Hudson, 1997), 259.
} 
"regurgitating" and the juxtaposition of art historical concepts, such as the universalism of modernism and the modernist attachment to the author for authenticity. The physical transmutation of the oral remnants thus exacts a similar outcome to the signification of the gnawed remains. Through an external process of myth making, the signification of the gnawed remains is deformed to form another "myth," emptying the full signifier to make an empty one.

Barthes wrote that "[j]ust as with Freud the manifest meaning of behavior is distorted by its latent meaning, in myth the meaning is distorted by its content., ${ }^{55}$ Within the context of art making, Antoni shifts behavior (her gnawing and "regurgitating” of the chocolate cube and the lard cube) into a signifier, converting Freudian associations into signifiers within a newly developed sign for eating disorders. The performative actions on the chocolate and lard can easily be viewed as Freudian in terms of oral fixation. However, the juxtaposition of the art historical and the physical (Antoni’s actions), negate psychoanalysis and force it to the surface in the role of signifier.

Most interesting is that a removal of gender occurs through the Freudian signifier. In describing the oral stage of infantile sexuality, Freud explains the following: "In this early period a loose sort of organization exists which we shall call pre-genital [.] The contrast between masculine and feminine plays no part as yet; instead of it there is a contrast between active and passive, which may be described as a forerunner of the sexual polarity with which it also links up later." ${ }^{\text {56 }}$ This pre-genital, degenderized aspect is an important feature in Antoni's approach. It fulfills the first part of a duplicitous

\footnotetext{
55 Roland Barthes, Mythologies, 122.

${ }^{56}$ Sigmund Freud, A General Introduction to Psychoanalysis (Garden City, NY: Garden City Publishing Company, Inc., 1938), 287.
} 
mythological system in all three components of Lard Gnaw, Chocolate Gnaw and Lipslick/ Polythylamine Display.

Both Lard Gnaw and Chocolate Gnaw signify, with the facial and dental impressions (respectfully), a primal, innate desire that is compulsive, which feeds into the sign of Freudian infantile sexuality. The media, however, do not seem to have genderless signification. Therefore, the medium and the facial and dental impressions function as collaborative signifiers. Linda Weintraub confirms this by reflecting differentiating gender responses, when she states the following: "Men are aroused by the erotic implications of obsessive nibbling and licking. Women, on the other hand, respond with repulsion. ${ }^{, 57}$ This repulsion, Weintraub continues, is linked to representations in multimedia of the need to "slim down" for women, and this reaction is similar in younger and older women. Large amounts of either substance if consumed, would cause a negative physical response for either gender. However, notions of consumption clearly provide differing social significations for each gender, which are culturally specific and connected to the performative act and the respective substance.

However, in a wider sense Antoni states, “[m]aybe we're in a bulimic society we are addicted to that fast fix and then throw it away. Maybe that's what packaging is; it's all for immediate satisfaction, then it is discarded. ${ }^{, 58}$ The physical signifiers of gnawing and the substances gnawed feed into the final part with their inclusion, literally, in Lipslick/ Polythylamine Display, which becomes a mythical signifier in this commentary on "bulimic society." The gobs of lard and chunks of chocolate, now embodied with a history of Antoni’s gnawing and "regurgitation," are distorted in their new found

\footnotetext{
${ }^{57}$ Linda Weintraub, Art on the Edge and Over (Litchfield, Conn.: Art Insights Inc., 1996), 127

${ }^{58}$ Linda Weintraub, 127.
} 
representations of lipstick and chocolate heart containers, forming a new myth reflective of a capitalistic need to socialize women. The genderless, minimal cubes become imbued with new significance in the context and presence of the Lipslick/ Phenylethylamine Display, with its commercial features and stereotypical female contents, thus prompting a questioning of gender identity and the effects of culture to determine it. Unlike Levine's or Sherman's, Antoni's specific gender is never revealed in the artwork. Rather, her physical presence is simply referenced through the facial and dental impressions in the two feet cubed blocks of lard and chocolate. Antoni, however, is a pluralistic artist. She does not restrict her modality of making. She does not only rely upon minimalist forms to produce a phenomenology in the viewer/ participant, in order to create plurality. In the next chapter, a work made between 1993-1994, Lick and Lather (Fig. 7 and Fig. 8) will be discussed. This is a work in which Antoni's representational "portrait” is physically engaged through licking and lathering by the artist, again producing a phenomenological experience that distorts conventional myths of identity. 


\section{Chapter Eight: Janine Antoni’s Lick and Lather}

In another artwork made between 1993-1994, Antoni shifts from simply referencing her physical presence to depicting herself in a representational mode. With Lick and Lather (Fig. 6 and Fig. 7), a series of duplicitous busts were made by casting the artists face. Media, as in Gnaw, were instrumental in establishing the dichotomy. One set was made of chocolate and the other of soap. However, unlike Gnaw, where the remains of the chocolate and lard were refashioned into a cultural and commercial identity in the form of "lipslicks" and heart-shaped chocolate packages, identity was worn away in a performative process leaving the busts in a state of varying states of androgyny. For the chocolate busts, the artist "passionately licks the image of her corpse, recreating herself in multiple variations." ${ }^{59}$ The soap busts were eroded with Antoni in the bathtub, where handling caused them "to resemble the faces of ancient monuments that have endured centuries of fondling and harsh weather."60

Again, menial, everyday tasks are performed by an unseen Antoni evoking the body politic and the “docile body” of everydayness. Indulgence, an unclean act, is countered by bathing. The binary opposition of structuralism is alluded to through the media and the artist. Antoni's actions were imbued with a multitude of cultural meanings that questioned conventional myths of femininity. The artist continues to 'speak' the object, making her actions operational. It is from this position that the artist is able to politicize her speech and form the counter-myth through the history of her actions. However this creation of the phenomenological through the conceptual continuation of

\footnotetext{
59 Jeffrey Deitch, Irrational Concepts: Nine Essays on American Artists in the Saatchi Collection (Great Britain: The Pale Green Press, 1996), 10.

${ }^{60}$ Jeffrey Deitch, 10.
} 
the activity, as discussed with Gnaw, by the viewer is nullified, due, in part, to Antoni's changing visage represented through the cast media. It is also diminished through the intimacy of Antoni's actions. The presence of the chewed remains in Chocolate and Lard Gnaw did not determine the location of activity. Eating is as much a social activity as it is a private one. However, Lick and Lather invokes a privatization of action, unseen actions that are meant to remain unseen, such as sex and bathing.

The medium of chocolate links Gnaw to Lick and Lather, however, its signification seems to shift from one to the other due to Antoni's aesthetic strategies. In Gnaw, the phenomenological effect is emphasized by the minimalist cube that directed the attention away from the object and toward the viewer. This, however, is not the situation with Lick and Lather. The "otherness" that was avoided through the plurality of conceptual participation is embraced in this work, forcing a dialogue of “otherness” in society and within us, the viewers. Lick and Lather is metaphysical in its approach to feminine identity. Authorship is dismissed due to the "otherness" of self that Antoni represents through the multiple, eroded cast 'selves' that differentiate from one another depending upon the time and activities spent with each. Antoni represents a fragmented self, and this fragmentation resists authorship, because it refuses closure.

Metaphysical philosophies are divided, when it comes to the question of identity. The key question is does identity remain constant over time? Or does identity change over time to the extent that separate selves are created? For example, is a person the same person, he or she was a year, month or even a day previously? Externally, it seems absurd to think that a person's identity changes. A person uses the same name over time, has shared memories over time, and certain elements of classification do not seem to change. 
One’s gender, race and place of origin do not change with time. However, internally, as one recollects certain stages of his or her life, it seems strange to think that one is the same person as he or she was when, for example, one was in the third grade or after a defining experience such as war or giving birth. The problem of identity over time is, perhaps, irreconcilable. For myth, however, the idea of a fixed or continuous identity allows myth to seem 'natural.' Antoni's physical interaction with the busts changes their visage and also challenges the notion of continuous identity. All begin as identical visages and are changed by her physical interaction.

In a recent interview, Antoni commented on this question of identity and its relationship to change and time, when she stated that she was thinking about the "erasure of this specific personality," ${ }^{, 61}$ when creating Lick and Lather. For Antoni the relationship of identity and representation is one of conflict. To represent something is an attempt to fix it in time, be it a long period of time or a short period of time. For Antoni the selfportrait is one presented to the world, it is a public image of oneself. She goes on to ponder, "I guess my question was- is that an accurate description of the self? And are we more ourselves alone at home eating a meal or in the bathtub, in these everyday activities. ${ }^{\text {62 }}$ The idea of the changing self according to context challenges the semiology of myth. Myth employs tautology for justification. In terms of identity for example it may simply say, "You are who you are.” This tautology provides a sense of proverbial truth, a stability, necessary for myth to function, but it is here that myth reveals itself. By defining like by like, myth performs "a magical act ashamed of itself, which verbally 
makes the gesture of rationality, but immediately abandons the latter, and believes itself to be even with causality because it has uttered the word which introduces it.”63

In order to understand how myth is tautological in structure, one must remember that myth today is discontinuous and based upon a phraseology, rather than, an epic narrative, this phraseology is composed of stereotypes, which can form the identity of the Other. The epic narrative attempted to explain the world and humanity as a product of this world created by a higher power. Phraseology, a corpus of stereotypes and generalizations by contrast, is by contrast a pseudoscience, in which observation, a key component of the scientific method, is manipulated by myth, in order to establish an "understanding” of diversity within a society. Unlike the epic myth, phraseology is adaptive to progress and change, removing the historicism of epic myth and replacing it with a sense of the modern, the now. Thus, the mythical is made by affixing, not a narrative, but a "taxonomy" of thought and associating “perceptions" to those who attempt to disrupt it. In terms of modern America, all one must do to gain an understanding of the mythical is think of the number of associations built upon the word “Hippie,” and more importantly how those associations have shifted during later decades in order to conform to the body politic. Barthes provides insight by stating the following: "Contemporary myth is discontinuous. It is no longer expressed in long fixed narratives but only in 'discourse'; at most, it is a phraseology, a corpus of phrases (of stereotypes); myth disappears, but leaving - so much the more insidious - the mythical."64

\footnotetext{
${ }^{63}$ Roland Barthes, Mythologies, 152.

${ }^{64}$ Roland Barthes, “Change in the Object Itself: Mythology Today,” in Image Music Text (New York: Hill and Wang, 1977), 165.
} 
The mythical demands simplicity. The very question of the nature of identity threatens myth, because it threatens the stereotypes that reinforce mythical speech. On the preservation of myth, Barthes commented that "[i]t is frozen in to something natural; it is not read as motive, but as a reason." ${ }^{, 65}$ If motives were revealed, then so too the body politic would be revealed. By addressing the question of identity through the repetition of her represented self and its changing visage through her interactions with them, Antoni destabilizes the idea of fixed identity, which stereotypes are dependent upon, in order to "naturalize" myth. This destabilization reveals the false nature of the myth of fixed identity. The idea of a fixed identity is a necessary one in order to impose authorship upon the artist and close the Text.

Antoni's use of repetition of the cast self demonstrates the elasticity of identity and art's inability to encapsulate the self pictorially. Identity can not be fixed, be it continuous or not. However, myth requires this not to be the truth or else its motives will be revealed, and the body politic, which relies upon the "docile body" for control, will be exposed as the maker of the myth. The idea of representing the self is in fact a means of closing the Text. Antoni's idea of 'erasure' is a strategy of removing false representation (myth) in order to obtain figuration. In regard to the licking and bathing of Lick and Lather, Antoni stated the following: "It's modeling in the sense that when you carve, you start with a block and you remove from it. But what I am doing is starting from a representation of myself and then removing from it.,

In this removal, figuration occurs through the unseen self of Antoni’s actions.

\footnotetext{
${ }^{65}$ Roland Barthes, Mythologies, 129.

${ }^{66}$ Janine Antoni quoted by Art:21, http://www.pbs.org/art21/artists/antoni/clip2.html, accessed on $10 / 28 / 2004$.
} 
Ewa Lajer-Burcharth discusses how Antoni 'speaks' the stereotype through her actions upon the soap and chocolate, when she states, "Antoni enacts stereotypes of femininity, yet rather than taking an ironic distance from them, she inhabits and undoes them from within, thus exposing the extent to which a woman is both embarrassingly caught and capable of reformulating her entrapment. ${ }^{, 67}$ As Antoni licked the chocolate busts and bathed with the soap ones, her actions endowed the objects with an eroticism invoked by her activities. This eroticism of the unseen body and actions of Antoni produces a figuration that usurps the myth of representation. Barthes distinguishes between figuration and representation, by explaining that "[f]iguration is the way that the erotic body appears (to whatever degree and in what ever form that may be) in the profile of the text. Representation on the other hand is embarrassed figuration, encumbered with other meanings than that of desire: a space of alibis (reality, morality, likelihood, readability, truth, etc.)." ${ }^{, 8}$ Thus, Antoni's work produces figuration, whereas, the cast multiples signify representation, an embarrassed figuration, embarrassed due to the associations of the body politic and its agent myth. This semiologically endows the cast visages of Antoni with a false reality of complacency associated with the "docile body." Representation always produces this false metaphysical “truth,” which denies desire. Figuration on the other hand is a production of desire.

Lajer-Burcharth comments on this condition of figuration that Antoni's actions produce, when she states the following: "Licking and lathering, the artist modifies not only the physical body but also the symbolic capacity of the portrait bust as a genre that

\footnotetext{
${ }^{67}$ Ewa Lajer-Burcharth, “Antoni’s Difference,” in Janine Antoni (New York, NY: Ink Tree Press 2000), 70 .

${ }^{68}$ Roland Barthes, The Pleasure of the Text (New York: Hill and Wang, 1975), 55-56.
} 
secures an intelligible and meaningful image of the self. The different, unflattering altered versions of Antoni's face undermine the idealizing effects of self-portraiture and, even more, its very powers of resemblance, its claim to physiognomic truth, and through it, to any other kinds of truths and historically gendered values[.]"69 In other words, Antoni's actions upon Lick and Lather negate the semiological construct associated with the representational depictions of her multiple, cast “selves,” which through their plurality refuse individuation and thus any notion of authorship.

Antoni, the unseen figure, invokes a figuration to occur. One in which the erotic body can appear through her absence, without 'embarrassment,' and in the presence of the representation- the agent of the body politic, the producer of myth- which is demonstrated through the mythologically saturated depiction of Antoni's chocolate and soap busts. This concurs, in part, with the artist, Mary Kelly (b. 1941), who stated that “[l]earning to speak depends upon the ability to conceptualize absence and establish differences." ${ }^{, 70}$ Antoni does both. Through the juxtaposition of representation and figuration, which is produced through her actions upon the cast portraits, she speaks the difference and thus undermines myths of femininity associated with female depiction, replacing them with the history of her activities.

Antoni produces figuration via an intimate “touch.” Licking, lathering, tasting, bathing are not experiences that can be represented as they are. Instead, any attempt to represent such experiences is easily dismissed as lacking truth, for such things are ineffable. The artifice of the cast "selves" is revealed by her unseen actions upon them,

\footnotetext{
${ }^{69}$ Ewa Lajer-Burcharth, Antoni’s Difference,” in Janine Antoni (New York, NY: Ink Tree Press, 2000), 56.

${ }^{70}$ Mary Kelly, Imaging Desire (Cambridge: The MIT Press 1996), 3.
} 
which embody Antoni’s figure through absence. The body is the sight of the phenomenological and these changing visages merely become objects acted upon. The visual effects of touch remind the viewer of the living, feeling body that is removed, and that as Husserl explains "the body is, in the first place, the medium of all perception; it is the organ of perception [.] " ${ }^{, 1}$ Lick and Lather encourages the viewer to conceptualize the intimate experience of the body, now absent. This unseen body which produces figuration through "touch" exemplifies notions of Luce Irigaray, when she states the following: "[T]he predominance of the visual, and of the discrimination and individualization of form, is particularly foreign to female eroticism. Woman takes pleasure more from touching than from looking, and her entry into a dominant scopic economy signifies, again, her consignment to passivity: she is to be the beautiful object of contemplation.,72 The cast representations, the objects of contemplation, which were intended to define Antoni are instead informed not by the body politic, but by the "touch" of Antoni, and in doing so, Antoni refuses the "docile body” of this dominant scopic economy.

This rejection of the "docile body" is also seen through signification. Originally set up facing one another with the chocolate busts opposing the soap ones, the mythical construct that Antoni had made with Gnaw is inverted and lacks a resolving signifier, like the Lipslick/ Phenylethylamine Display. Nevertheless, Antoni is still engaged in a type of mythical speech. The culminating signifier is Antoni herself and the actions of licking and bathing, which signify, akin to Gnaw, a Freudian signification. A reduction to the

${ }^{71}$ Edumond Husserl, Ideas Pertaining to a Pure Phenomenology, Second Book, translated by R. Rojcewicz and A. Schuwer (Norwell, MA: Kluwer Publishers, 1998), 61.

${ }^{72}$ Luce Irigaray, "The Sex Which Is Not One,"in Writing on the Body: Female Embodiment and Feminist Theory, Conboy, Medina and Stanbury, ed.s (New York: Columbia University Press, 1997), 250. 
genderless oral stage of infantile psychosexual development is not the objective of the myth here; rather an unresolved duplicitous signification of desire and denial is signified. Referring to Gnaw, Jeffrey Deitch points out that the chocolate and lard also serve as signifiers that "provoke the comparison of dark and light, dirty and clean, desire and denial." ${ }^{, 73}$ These signifiers are given a primary position with Lick and Lather, and it is important to note that "a signified can have several signifiers."

As the viewer walks between, the two sets of busts, he or she is placed between these opposing signifiers, and becomes a signifier of conflict between them. Thus, as with Gnaw, the viewer is thrust into an empathetic, phenomenological position that makes use of historicism of minimalism to form the myth. "Ancient or not, mythology can only have a historical foundation, for myth is a type of speech chosen by history; it cannot possibly evolve from the 'nature' of things." ${ }^{\text {,75 }}$ The Western tradition of the portrait bust is also a signifier for Antoni's myth in Lick and Lather. Repetition, a minimalist strategy, is appropriated by Antoni here and, to a lesser degree, with Gnaw. However, this usage reaffirms the historical president of the portrait bust in Western culture.

Within the deconstructive preamble of "art being born of imitation,,"76 Antoni embraces the use of the outline to reinforce mythical content. The variously eroded visages of her self give way to the contours of the classical portrait bust, repeated seven times in each medium. "The outline (design or melodic line) is not only what permits imitation and recognition of the represented in the represented. It is the element of formal

\footnotetext{
${ }^{73}$ Jeffrey Deitch, 10.

${ }^{74}$ Roland Barthes, Mythologies, 120.

75 Ibid., 110

76 Jacques Derrida, Of Grammmatology, translated by G. C. Spivak (Baltimore, MD: The Johns Hopkins University Press, 1976), 208.
} 
difference which permits the contents (colored or sonorous substance) to appear.,"77 Barthes mythical system does not conflict with Derrida, in terms of repetition. Barthes reiterates that " $[\mathrm{t}] \mathrm{his}$ repetition of the concept through different forms is precious to the mythologist, it allows him to decipher the myth; it is the insistence of a kind of behavior which reveals its intentions." ${ }^{\text {78 }}$ Therefore, Antoni’s two-fold duplicity provides this kind of repetition of the outline. The face, through casting, is a repetition of her own, and the form of the portrait bust is a repetition of Western history, both through the use of outline for recognition. With Lick and Lather, both a literal outline and a conceptual outline were “eroded” by Antoni. In the following chapter, Loving Care (Fig. 9 and Fig. 10) performed and "made" by Antoni in 1993 will be examined. This work demonstrates that the deconstructive act of "eroding" outline can be made a constructive act of creating a conceptual, temporal outline through the performative act.

\footnotetext{
${ }^{77}$ Jacques Derrida, Of Grammatology, 209.

${ }^{78}$ Roland Barthes, Mythologies, 120.
} 


\section{Chapter Nine: Janine Antoni’s Loving Care}

In contrast to the "erosion" of the outline in Lick and Lather though the performative aspect of licking and bathing the busts, a 1993 performance titled Loving Care (Fig. 9) creates an outline through the performance. Thus, the performance functions again as an insertion into the mythology that Antoni simultaneously assembles and deconstructs. Deitch succinctly states that "[i]n Loving Care, one of her major works subsequent to Gnaw, she drenches her hair with black dye and mops the floor with it, and in this devotional ritual takes on the history of recent painting.,"79 In both Gnaw and Lick and Lather, the physical body's action was referenced through its effects and subsequent history, which is infused with the performance-based object. In Loving Care the artist's actions are not private, but made public to an audience of gallery-goers, seemingly shifting its significance. Nevertheless, the mythology functions in a similar system. The connection to the body in all three major works discussed has been the crucial signifier for revealing significance and mythical structure. Loving Care is no different. By shifting attention to the Anthony D’Offay Gallery floor, the seemingly pure performance is instantly removed and placed in similar terms of the performance object, making Antoni once again a historical signifier of the work.

The medium and its outline(s) (historical references) of Loving Care become quite similar to Gnaw and Lick and Lather. The hair dye signifies both the use of paint and the commercially infused desire to change one's appearance. Therefore, an analogy to the "lipslicks" of Gnaw can be made. The use of her own "living” hair as the "brush" during the "mopping” of the floor signifies a general critique of the history of painting,

\footnotetext{
${ }^{79}$ Jeffrey Deitch, 10.
} 
where the majority of paintings of women were made by men. This also seems to allude to the painting method of Jackson Pollock (1912-1956), where removing the canvas from the easel and painting on the canvas, on the floor, and without a support signified male genius. It is an ironic gesture, which paradoxically removes Antoni’s identity, while making her presence essential. RoseLee Goldberg states that "for her it was an ironic provocation of male-dominated legacies (in this case of Pollock and Klein), a frequent theme in her work. ${ }^{\prime 80}$ The use of a bucket, the floor and the act of mopping also serves as a signifier of the menial repetitive tasks traditionally reserved as women's work. The end result contradicts the Modernist notion of originality, just as Congo, the chimpanzee, did with his abstract painting in the 1970s. ${ }^{81}$ The floor being temporal and the need for documentation remind one of process art of the late 1960s and 1970s.

The problem of authorship, which is seen in Cindy Sherman's photographs, appears in Loving Care. The work is primarily known, not present for its making or fortunate enough to witness the floor of the Anthony D’Offay Gallery, but as a photograph of the performative signifier. The problem that this causes is iconographic. Unlike Gnaw and Lick and Lather, which are known through their performative conduits, Loving Care is known in process. Only one photograph that I have been able to discover shows it in any other way. In Janine Antoni’s monograph, Loving Care (Fig. 9 and Fig. 10) is shown without Antoni. The "presence" of Antoni's absence is profound. As with Gnaw and Lick and Lather, a Husserlian form is created. The viewer is compelled to phenomenologically “enter” the work. Antoni’s actions are not unique or privileged.

${ }^{80}$ RoseLee Goldberg, 137.

${ }^{81}$ During the 1970s Congo, a chimpanzee, produced a number of gestural abstract paintings after being taught by his caretakers. Congo’s paintings have an elegance and proficiency that challenge notions of "genius” associated with abstract expressionist painters. 
They are not the product of "genius," but are produced by a banal (and seemingly absurd) activity of using one's hair as a brush. Intially the gallery-goers functioned as on-lookers, and Antoni disrupted the visual activity of watching her in two ways. First as she "mopped" the floor, the viewers became physical participants by moving away from the messy activity. Second, the odor of the hair-dye must have been overwhelming to the senses. After Antoni’s activity ceased the space was "barred” from physical entry. The work produced was not iconic, but the product of a narrative, Antoni’s actions. In order to "enter" the work, the viewer had to visualize her activities. However, these were not only her activities, but those of the viewer. He or she had been a participant, moving in time and experiencing the odors produced by the chemicals of "beauty." Antoni’s method, being democratic, encourages the viewer to make the "leap" and "engage” Antoni's activities from a first person point of viewer, cognitively "becoming” the Author, and thus negating traditional notions of singularity associated with authorship and "genius." Antoni's intentions differ from those of Sherman, who attempts to reclaim the female body through her plurality of representations of her individual self. She is unlike Sherman whose authorship is based on the appropriated stereotypical female stereotype. Antoni attempts to avoid authorship in Loving Care through both her posturing and actions. Being on all fours in a regressive act, Antoni's physical presence becomes desexualized through its Freudian signification. She re-enters the pre-genital state, as also signified with Gnaw. Because she is wearing a black top and pants her physical sexuality is meant to be avoided as a primary signifier. She is not the nude female performance artist attempting to reclaim the female body. This differentiates her from feminist performance artists of the 1960s and 1970s, like Shigeko Kubota (b.1937), whose 
performance, Vagina Painting (Fig. 11), 1965, may have been similar in theme and intent, but made direct use of the female anatomy. Kubota, like Abramovic, is reduced to her "sex." 82 This gender reduction empowers myth by imposing authorship, which closes the Text.

One must now question why that the most proliferated image of the performance is not the one of the "painted” floor of the D’Offay gallery, but an image of process, which conveniently depicts the artist "frozen" on all fours with her rear end facing the camera. Antoni's figuration is removed with this photograph's presentation. Her depiction is a representation, embarrassed and culturally facilitated - a means to discredit her activity and reduce her to her "sex," which is a means of applying an authorship and closing the Text. Antoni's erotic body is removed. This is the problem of documentation. The photograph, which appears truthful, is merely a response to the appetites of myth. The counter-myth is difficult to produce due to the inductive qualities of myth, which Barthes comments upon, when he states that "it thus appears that it is extremely difficult to vanquish myth [.] [M]yth can always, as a last resort, signify the resistance which is brought to bear against it." ${ }^{, 83}$

With Loving Care this is accomplished with "documentation,” which through the photograph's composition and insertion of Antoni semiologically subjugates the artist through her depiction, which forces her to become, as Irigaray states, "the beautiful object of contemplation." ${ }^{84}$ Antoni's content is evaporated by myth, which reclaims her

\footnotetext{
${ }^{82}$ Moira Gatens, “Corporal Representations in/and the Body Politic," in Writing on the Body: Female Embodiment and Feminist Theory, edited by Katie Conboy, et. al. (New York: Columbia University Press, 1997), 84.

${ }^{83}$ Barthes, Mythologies, 135.

${ }^{84}$ Luce Irigaray, "The Sex Which Is Not One," in Writing on the Body: Female Embodiment and Feminist Theory, editied by Katie Conboy, et. al. (New York: Columbia University Press, 1997), 250.
} 
representation in order to distort her content. The image of Antoni, a supposedly detached “documentation," supercedes her intentions. She is silenced. She no longer 'speaks' the myth, but she is spoken 'of' or 'about.' Her reduction is 'fatal' to her 'speech,' becoming the "docile body" of Foucault, or as Laura Mulvey would state, "the bearer of meaning, not the maker of meaning.. ${ }^{85}$ The phenomenology of her action is almost completely lost, and instead myth distorts and evaporates Antoni’s ‘speech’ and counter-myth.

Perhaps, this occurs, in part due to Antoni actions. With Gnaw and Lick and Lather, the performative elements were unseen, and Antoni's absence and actions upon the materials, the chocolate, lard and soap, facilitated a phenomenological form, which shifted the viewer into the position of conceptual participant. Chocolate, lard and soap are all ephemeral materials; however, they remain more or less constant unless an action is placed upon them. The floor of the gallery is not. It is "tied" to Antoni, and soon after the performative action is completed the floor will most likely be cleaned. If the floor of the D’Offay Gallery had been removed, as Richard Serra’s “throwing lead” work, 1969, had been for Leo Castelli's gallery, the signification of the work would be similar to that of Gnaw and Lick and Lather, that is the emphasis would be placed upon the 'acted upon' object and its materials, not the "documentation" of the performance, which represents Antoni for scopic effect.

Thus, three elements are necessary for Antoni’s mythical speech: absence, object and actions. This work only supplies the latter. The object of the floor, which could have been physically retained, is not, and the nature of this performance is public, which negated the phenomenological form that produces plurality through conceptual

\footnotetext{
1975), 6-18.

${ }^{85}$ Laura Mulvey, “Visual Pleasure and Narrative Cinema,” Screen , 16:3 (London: Autumn,
} 
participation. Loving Care due to its structure, sacrifices its content for the content of the body politic, which 'speaks' through the semiological structure of myth. Perhaps, most fundamental is Antoni's absence, which opens the Text allowing the viewer to become the conceptual participant. Antonti 'speaks' work, through her actions. Her actions, however, are democratic, not the product of training or "genius." This encourages the viewer to become a cognitive surrogate for Antoni, replacing her "body" with his or her own, creating a phenomenological form and disrupting the authorship by making many "Authors.” Each produces a "text” of the work through conceptual participation in its making.

It is ironic then that some feminist critics would find fault with this element of ‘speech.' Ideas concerning authorship and subjectivity as Rosemary Betterton explains are a point of opposing difference for many feminists in regard to contemporary critical theory. She writes the following: "On one side, there are those who believe that women have a vested interest in the deconstruction of the powerful authorial figure defined within Enlightenment aesthetics, a tradition of mastery within a predominately white, male, Euro-centric narrative. On the other, are those who argue that women have too recently acceded to artistic identity and subjectivity to let it go.”86 Myth has, however, already supplied language with the content of the body politic, and if one uses the ready supplied language of culture, myth subjugates the speaker to the position of the author of the minority, thus reducing the Text and making the myth seem 'natural' by contrast. Antoni's absence, on the other hand, denies the myth the convenience of representation,

\footnotetext{
${ }^{86}$ Rosemary Betterton, An Intimate Distance: Women, Artists and the Body (New York: Routledge, 1996), 161.
} 
which would semiologically close the Text. Antoni’s absence removes the Otherness that myth wants to place upon her.

Thus, it seems strange that critics like Mary Kelly would denounce absence as a feminist tactic. She writes that "[t]he (neo) feminist alternative has been to refuse the literal figuration of the woman's body, creating significance out of its absence. But this does not signal a new form of iconoclasm. The artist does not protest against the lure of the picture. In another way, however, her practice could be said to be blasphemous insofar as she seeks to appropriate the gaze from behind it (the place of gods, auteurs, and evil eyes). ${ }^{, 87}$ The idea of appropriating the gaze from behind seems quite frankly absurd. The mental conception of woman is certainly distorted by myth; however, Antoni places the viewer in a context, a physical context, which stimulates the phenomenology of experience, creating a form. Her absence de-genders the work in such a way as to produce history through her actions - actions that enable the viewer to conceptually participate, removing Otherness, which subjugate the image of woman through the semiology of myth, as seen with the "documentation," the photographic representation of Antoni, of Loving Care.

To continue representing the self, as Cindy Sherman does, in order to be iconoclastic, is a thwarted effort. Such efforts 'to speak' the subject are negated by the myths attached to that language. A 'refusal of speech' through the unseen performance is a positive movement in reconfiguring the significance of the female image by demonstrating the inability of 'speech' to communicate meaning, making known that the semiology and content of the myth is archaic. Furthermore, Antoni's emphasis on

\footnotetext{
${ }^{87}$ Mary Kelly, Imaging Desire (Cambridge: The MIT Press, 1996), 124.
} 
"touch," which is invoked by her absence, feminizes the work removing it from the male dominated scopic economy. ${ }^{88}$ Antoni’s absence produces figuration, not representation. Kelly suggests a re-representation, which, due to the limitations of language, reinforces myth and Otherness.

If one were to encounter Loving Care with Antoni absent, then the artist would have been successful in the production of the counter-myth through the usage of the language-object, her actions upon the floor. Only through her physical absence is Antoni successful in manufacturing counter-myths, which re-evaluate the language of the myths produced by the body politic. This evaluation of Loving Care is not meant to discredit her, but simply demonstrate the tenacity of myth. Laura Mulvey reflects upon this difficulty facing Antoni, when she states that "[i]t cannot be easy to move from oppression and its mythologies to resistance in history: a detour through the no-man's land or threshold area of counter-myth and symbolisation is necessary [.] ${ }^{\prime 89}$ Furthermore, Antoni should certainly be viewed, not only an artist, but also as a writer. As such Barthes relates, "[w]riting is that neuter, that composite, that obliquity into which our subject flees, the black and white where all identity is lost, beginning with the very identity of the body that writes." ${ }^{90}$ Antoni ‘writes’ through her absence. Her absence from the work allows the viewer to engage the work in a phenomenological way, becoming the "Author," removing the singularity of authorship from Antoni. The "body" of the artist becomes inclusive. Identity becomes plural, shared.

${ }^{88}$ Luce Irigaray, “The Sex Which Is Not One,” in Writing on the Body: Female Embodiment and Feminist Theory, editied by Katie Conboy, et. al. (New York: Columbia University Press, 1997), 250.

${ }^{89}$ Laura Mulvey, Visual and Other Pleasures (London: Macmillan, 1989), 167.

${ }^{90}$ Roland Barthes, The Rustle of Language, 49 


\section{$\underline{\text { Conclusion }}$}

The myths Janine Antoni writes are in essence a type of history through which she interjects her own physical being, thus becoming a part of that history. Through her process of mythical speech, she decodes other myths of modernism's past and dispels them while paradoxically forming her own, in a never ending search for self in a commercially driven society that desperately grasps the classical construct of beauty as a marketing tool and a societal norm. Unlike her predecessors, such as Sherrie Levine who used appropriated images or Cindy Sherman who used herself in appropriated guises to dispel the stereotypical myths of women and society, Antoni manufactures counter-myths in a duplicitous approach that uses the history of art to comment on gender identity. By placing Freudian ideas in the role of the signified through her actions, Antoni creates myths that remove her gender identity to reveal the constructs that support traditional and contemporary notions of femininity. The mythical sign that the signifiers of the Freudian signified feed into is not a conclusion, but rather a question of what Ellen Berkovitch refers to as the "nature/nurture symbiosis"91 inherent in her work.

Antoni's actions are operational. She directly 'speaks'the myth without speaking 'of' or 'about' myths. As Barthes put it, she "speaks the tree,"92 which forms a languageobject. Antoni 'speaks' the myth through her actions, just as the tree cutter 'speaks' the tree. Her actions historicize the objects acted upon, and it is in her absence that her actions resonate, creating the second-order system of myth. The viewer through her absence is able to both imagine and conceptually continue her actions through the physicality expressed by the evidence of her actions upon her media, which are typically

\footnotetext{
${ }^{91}$ Ellen Berkovitch, 143.

92 Roland Barthes, Mythologies, 145.
} 
'of' or 'about' the body. The media - chocolate, lard, soap and/or hair dye evoke the feminine, and with this evocation the female is alluded to, but not directly spoken of. This allusion forces the viewer to question the proposed 'nature' of femininity, the semiology of myth facilitated by the body politic, which relies upon what Foucault calls the "docile body" to reinforce its ideologies.

Antoni's actions are those of everyday activities of eating, bathing or mopping the floor. They do not distance the viewer, limiting the Text. Instead, they embrace an "everydayness," and in doing so the body politic is revealed through a recontextualization of these activities. Together, the viewer/participant and Janine Antoni 'speak,' creating a plurality that refuses the singularity and the Otherness of myth, through the paradoxical creation of a new myth based upon the historical actions of Antoni, not the body politic. Antoni's works attempt to reveal the false conception of myth as being 'natural.' Instead, one recognizes that myth attempts to 'naturalize' norms that are social conventions of the dominant 'voice,' the body politic, through semiological structure. Antoni's actions thus produce figuration, rather that representation.

In certain works, such as Lick and Lather, Antoni juxtaposes figuration over representation to demonstrate representation's semiological relationship with myth. With Loving Care, figuration is suppressed by the representation of Antoni in the work's “documentation," which in effect mythologizes Antoni’s efforts through a long, established "scopic economy" that reduces her to an empty signifier of the myth. Of the works discussed, only Gnaw produces figuration without the presence of a representational likeness or depiction. Antoni's actions upon the minimalist cubes of lard and chocolate produce her "touch" upon the objects. With all of the works discussed, 
however, the presence of Antoni's “touch" is paramount in her 'speaking' the myth. It feminizes the myth according to Luce Irigaray who states, "Woman takes more pleasure from touching than from looking., ${ }^{93}$ This creates an intimacy through figuration, an intimacy that representation denies due to its semiological structure. Antoni's purpose in her mythical speech seems to be this intimacy of "touch.” She expresses this by stating the following: "My hope is that you as a viewer can feel that intimacy. That's what a portrait is - a way of getting close to the person it's depicting."94

${ }^{93}$ Luce Irigaray, “The Sex Which Is Not One,” Writing on the Body: Female Embodiment and Feminist Theory, editied by Katie Conboy, et. al. (New York: Columbia University Press, 1997), 250.

${ }^{94}$ Janine Antoni quoted by Art:21, http://www.pbs.org/art21/artists/antoni/clip2.html, accessed on $10 / 28 / 2004$. 
Figure 1: Sherrie Levine, Untitled (After Edward Weston), 1981, Photograph.

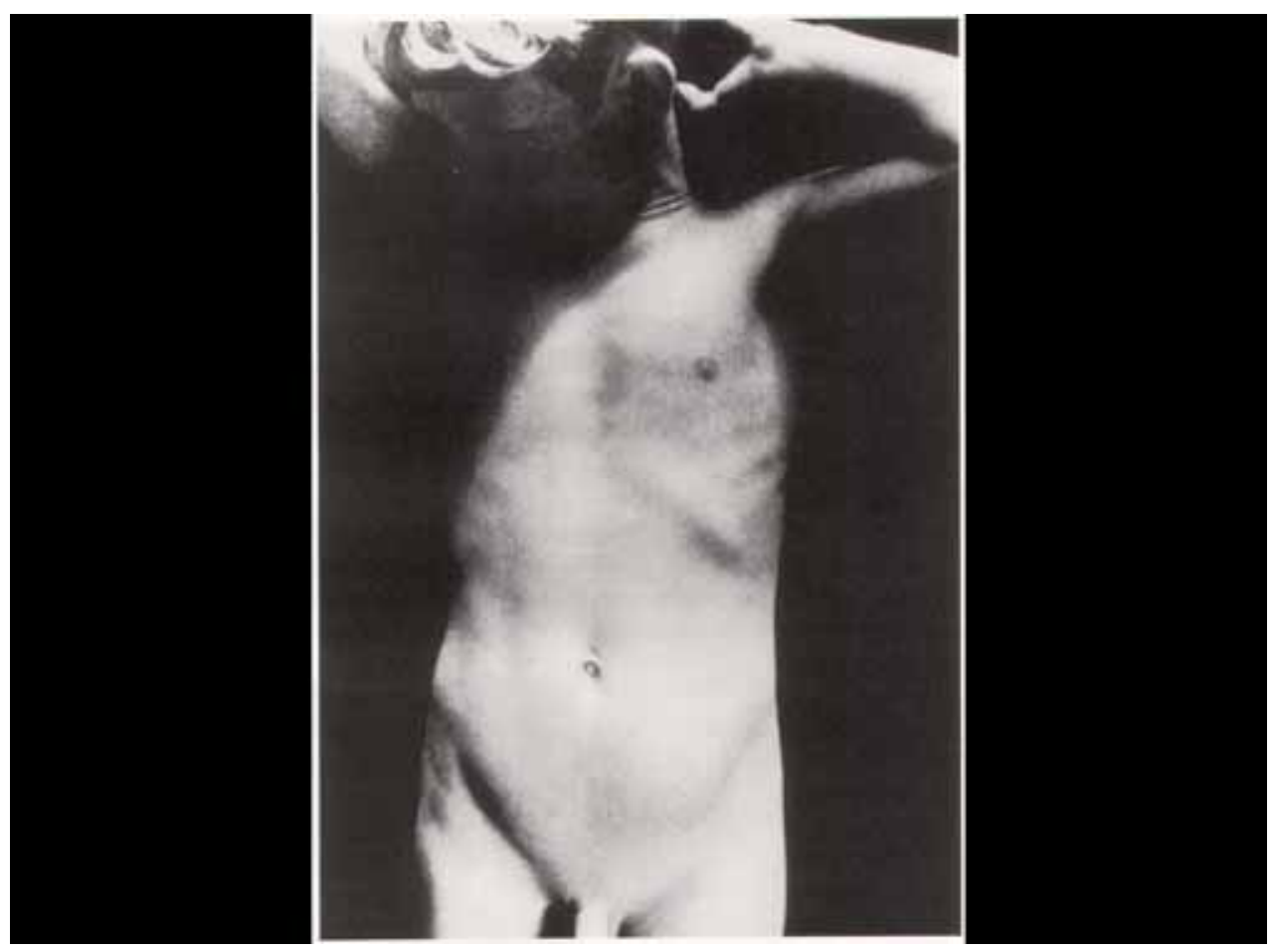


Figure 2: Cindy Sherman, Untitled Film Still \#3, 1977, Black and White Photograph.

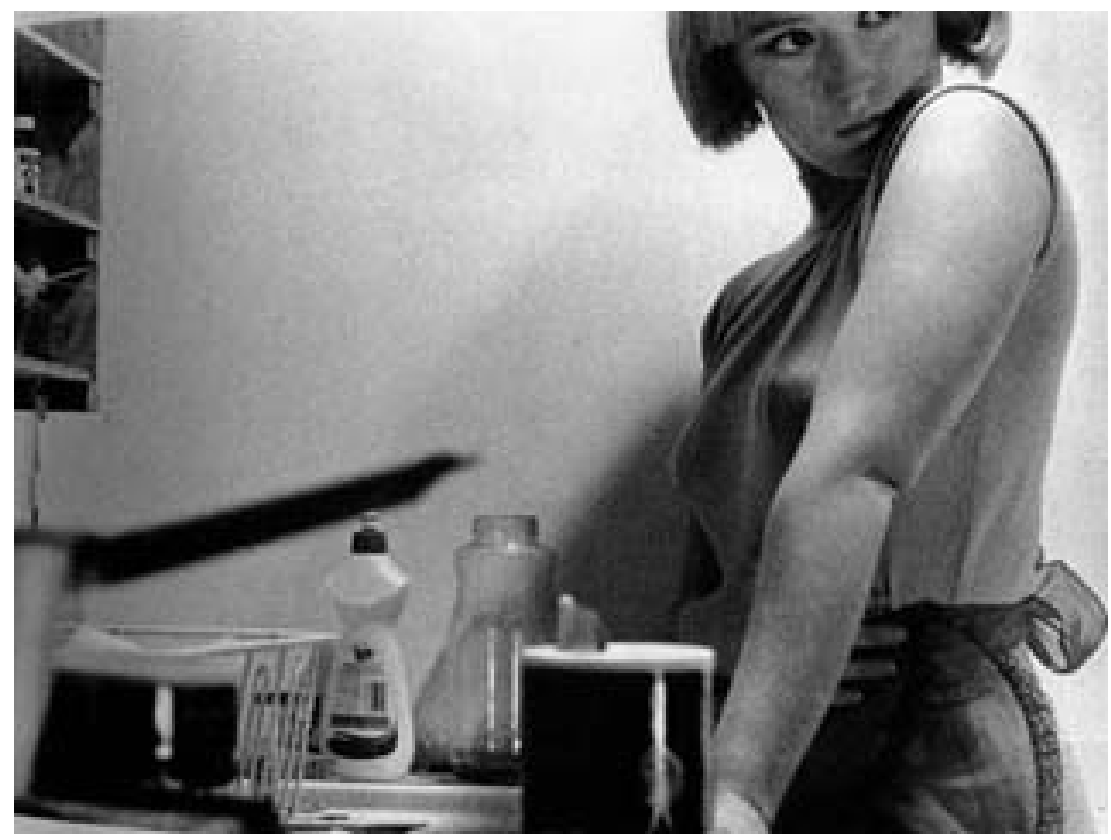


Figure 3: Janine Antoni, Chocolate Gnaw, 1992, chocolate.

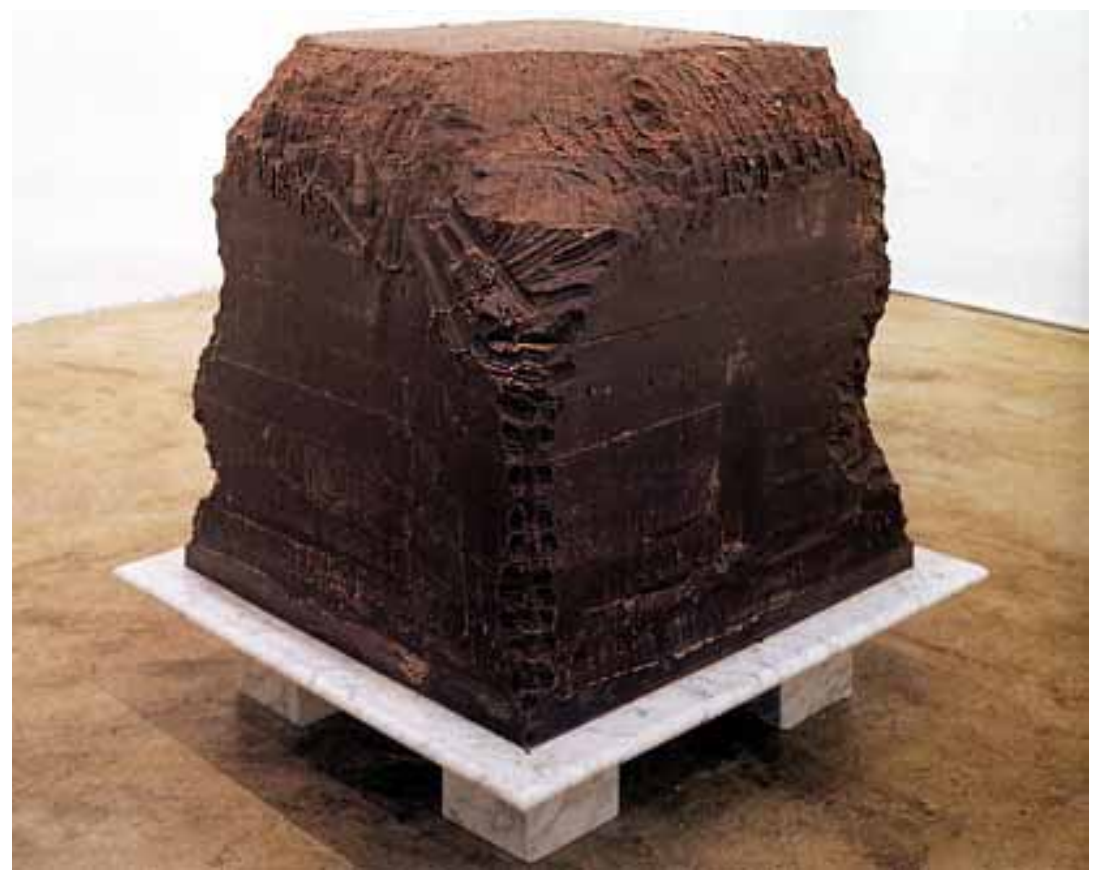


Figure 4: Janine Antoni, Lard Gnaw, 1992, lard.

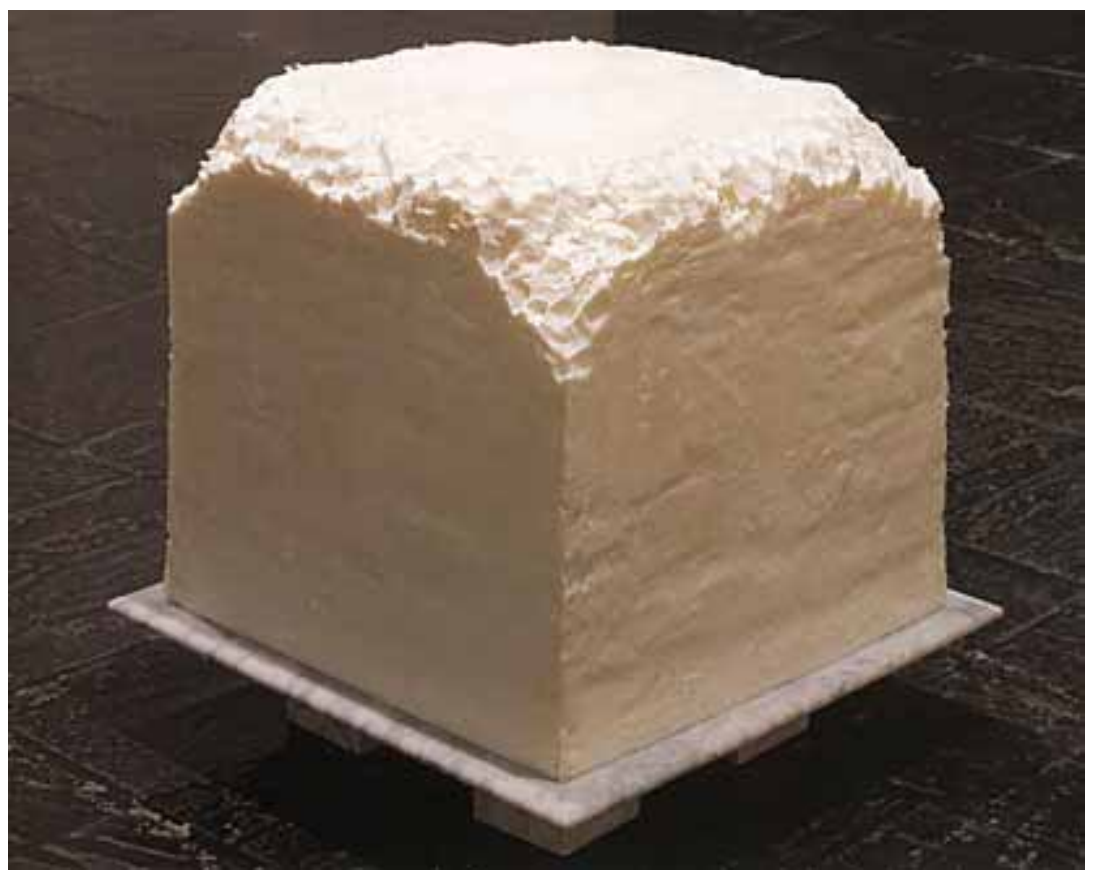


Figure 5: Janine Antoni, Lipslick Phenylethylamine Display, 1992, mixed media.

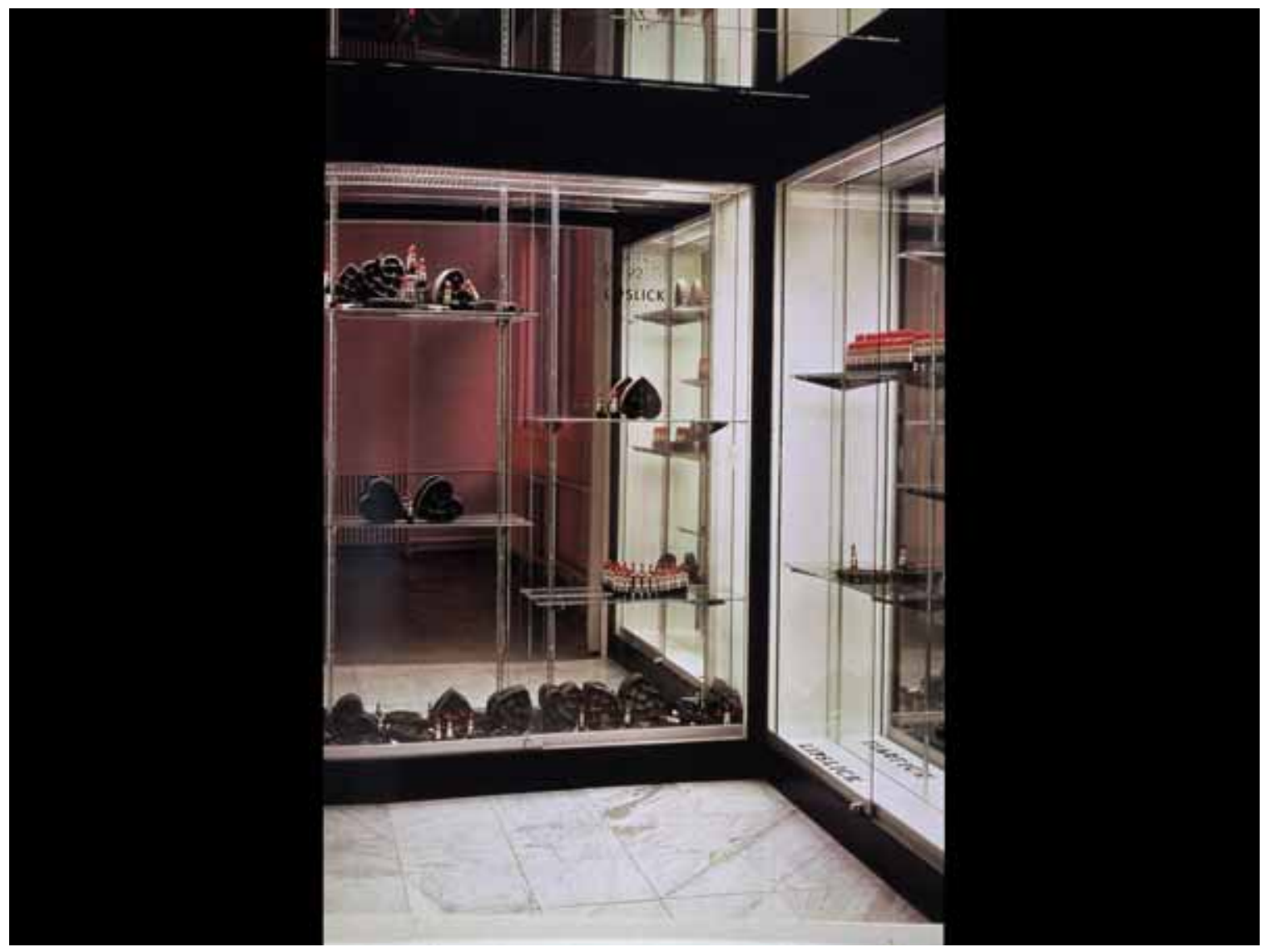


Figure 6: Tony Smith, Die, 1962, Steel, edition of three, 6x6ft.

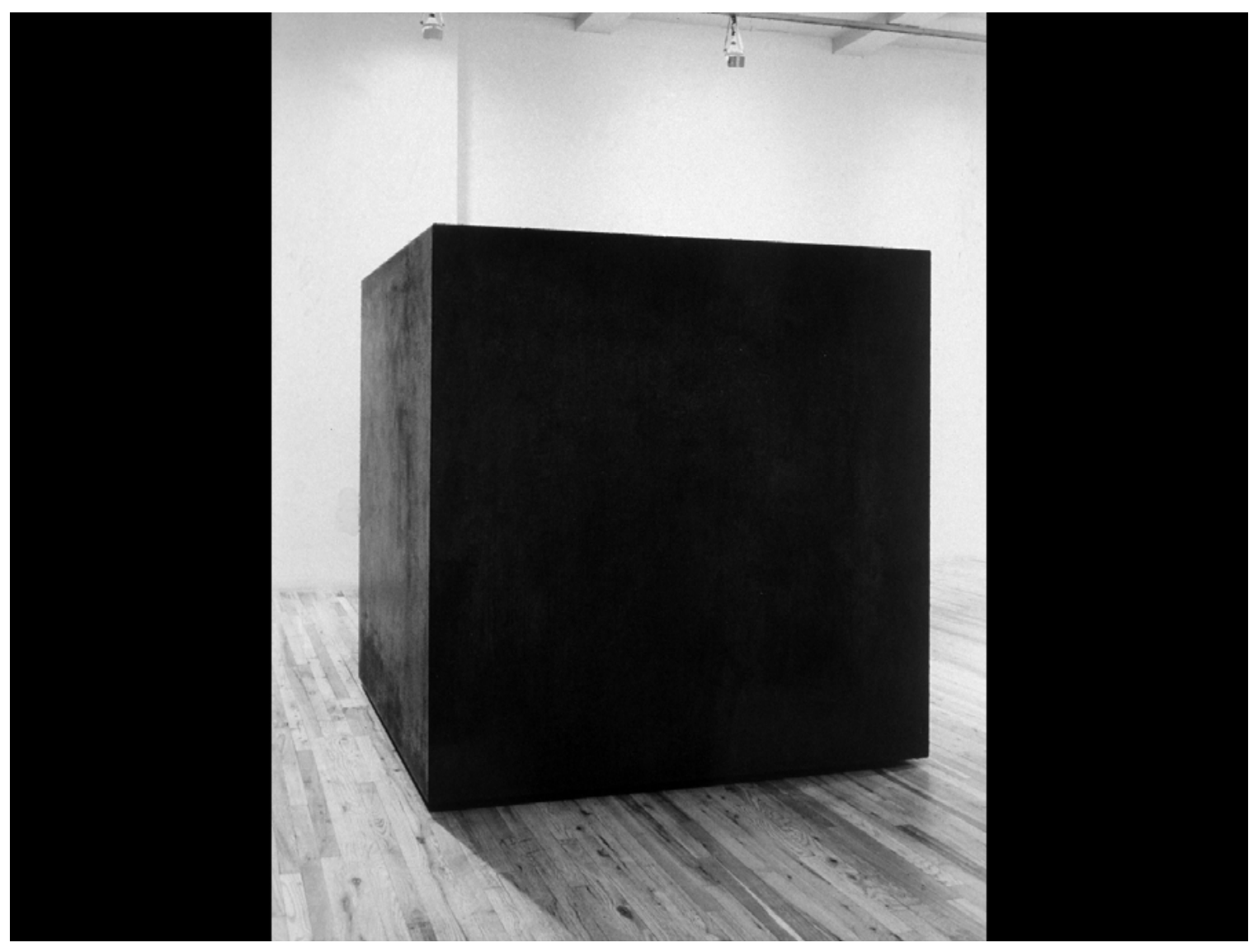


Figure 7: Janine Antoni, Lick and Lather, 1993-1994, chocolate and soap.

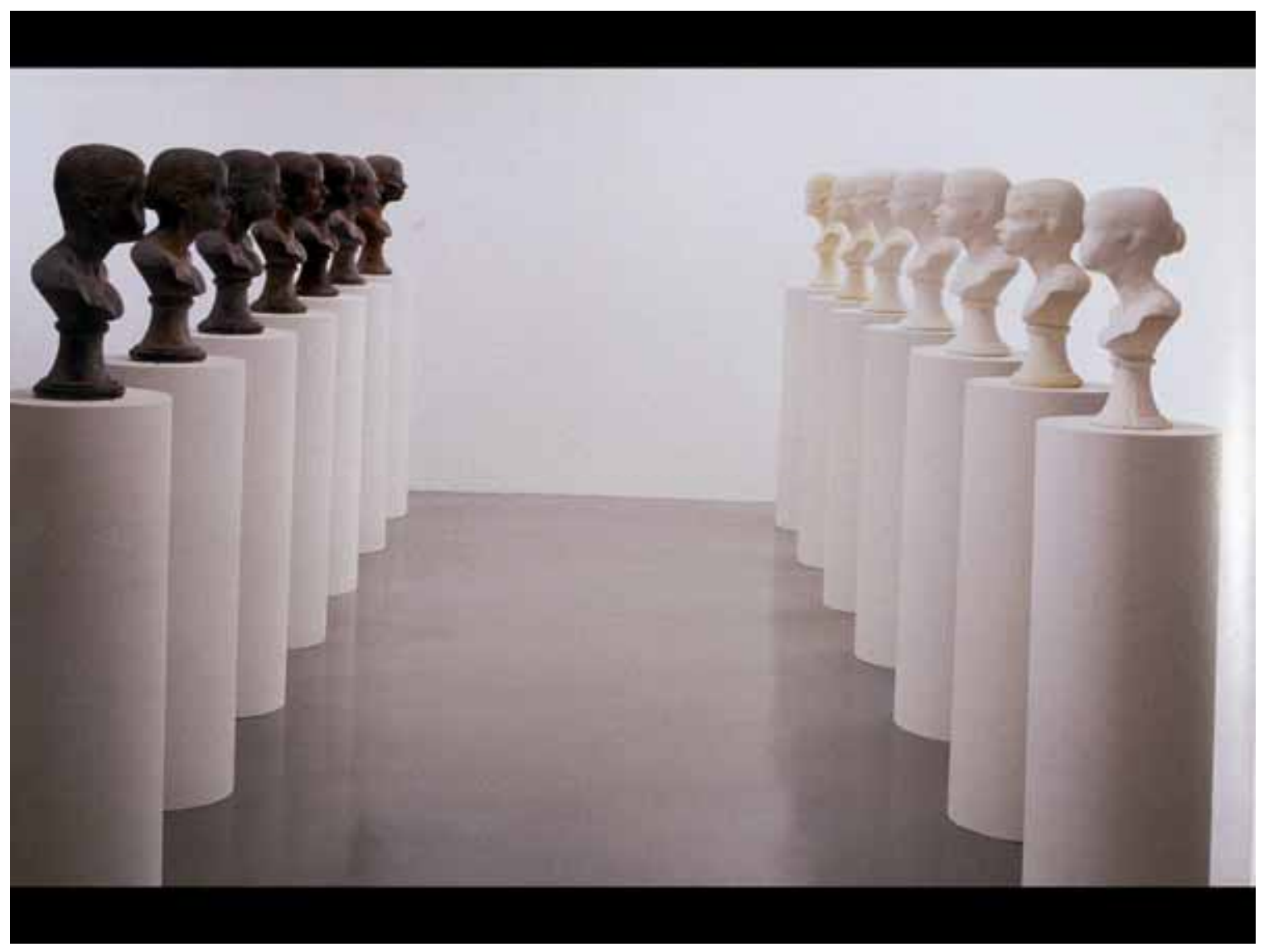


Figure 8: Janine Antoni, Lick and Lather, 1993-1994, chocolate and soap.

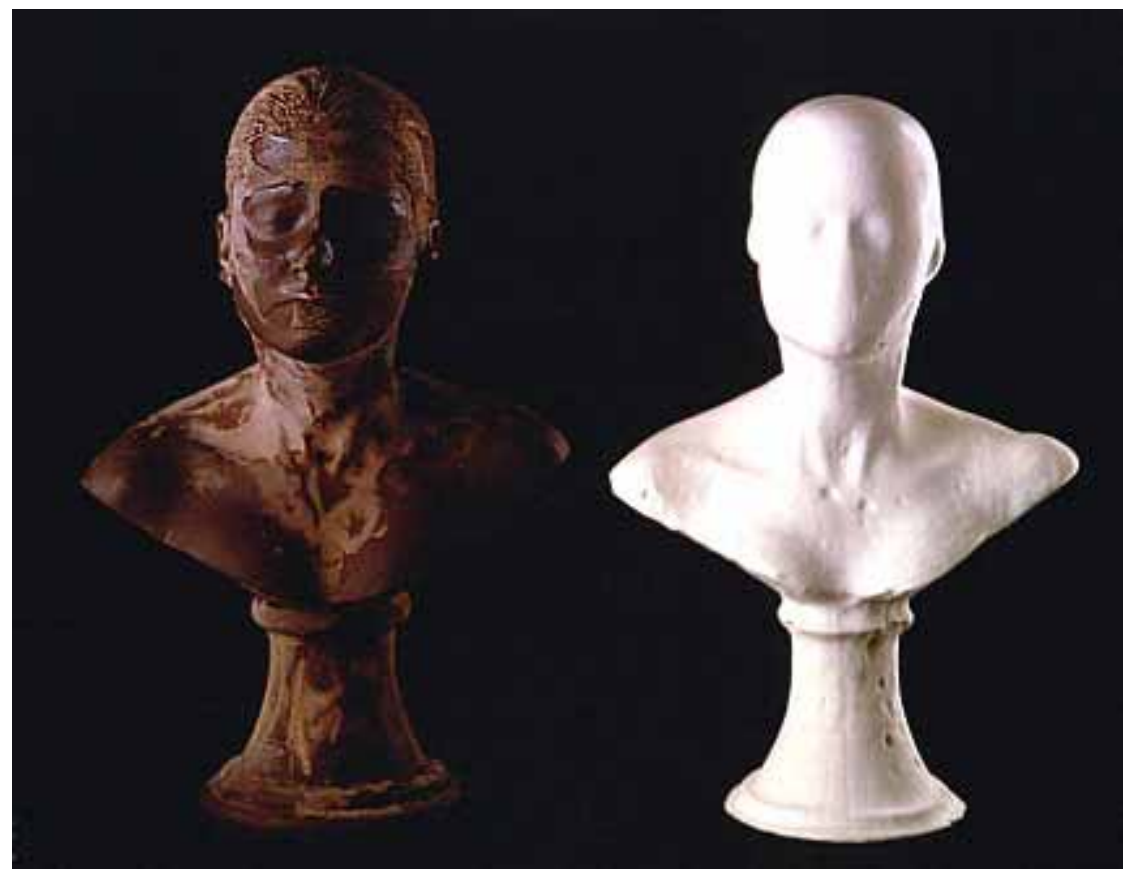


Figure 9: Janine Antoni, Loving Care, 1993, hair dye.

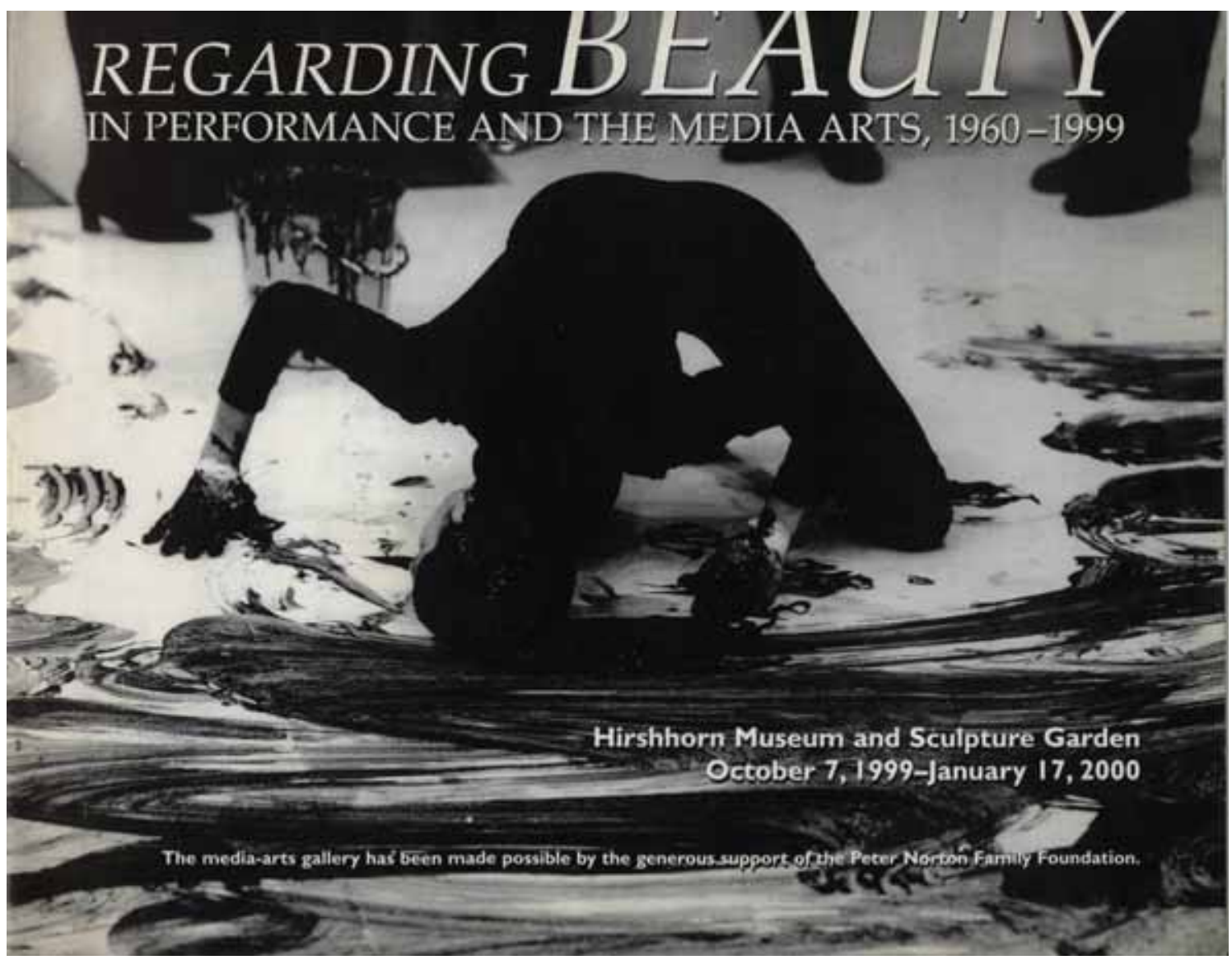


Figure 10: Janine Antoni, Loving Care, 1993, hair dye.

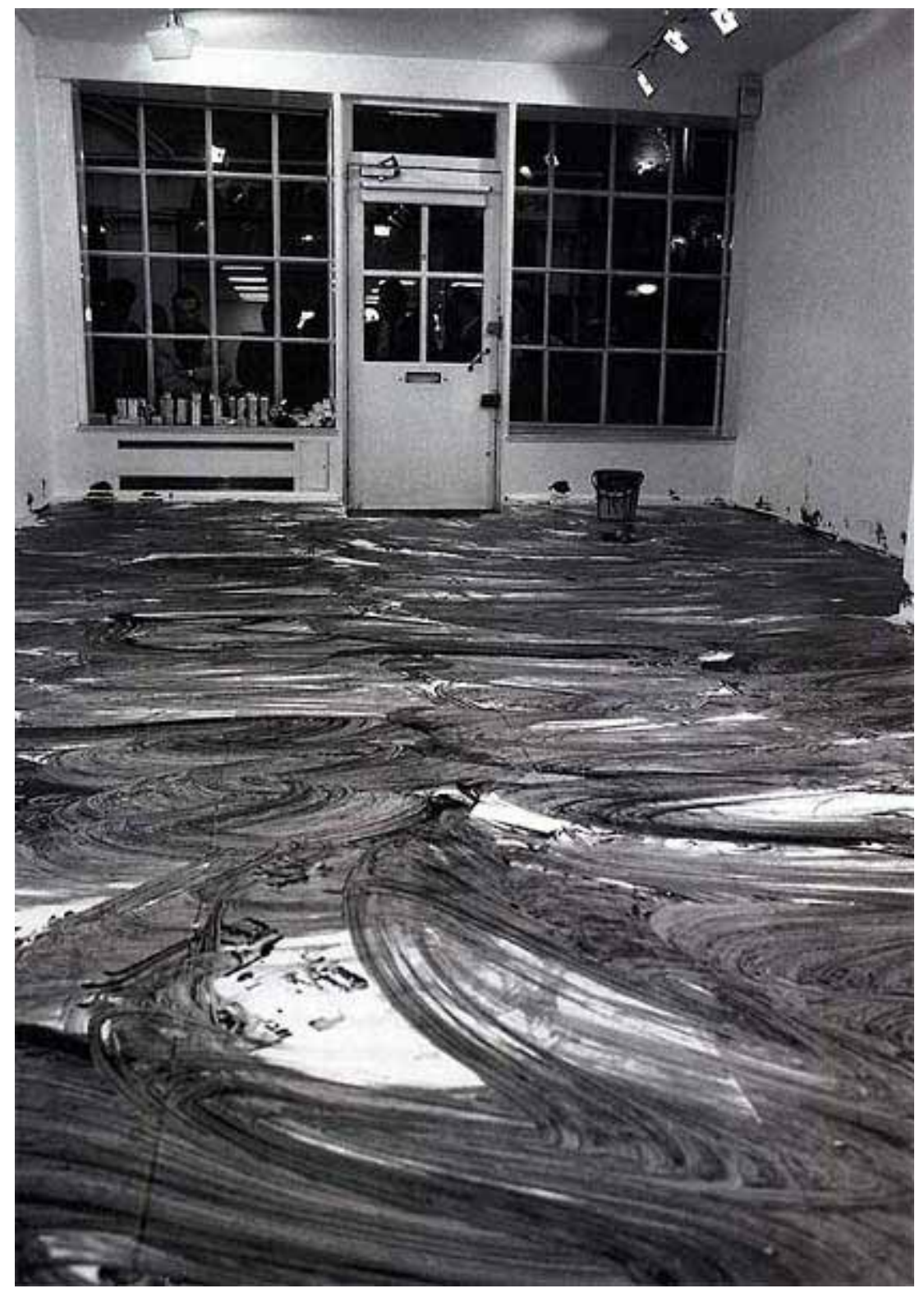


Figure 11: Shigeko Kubota, Vagina Painting, 1965, performance.

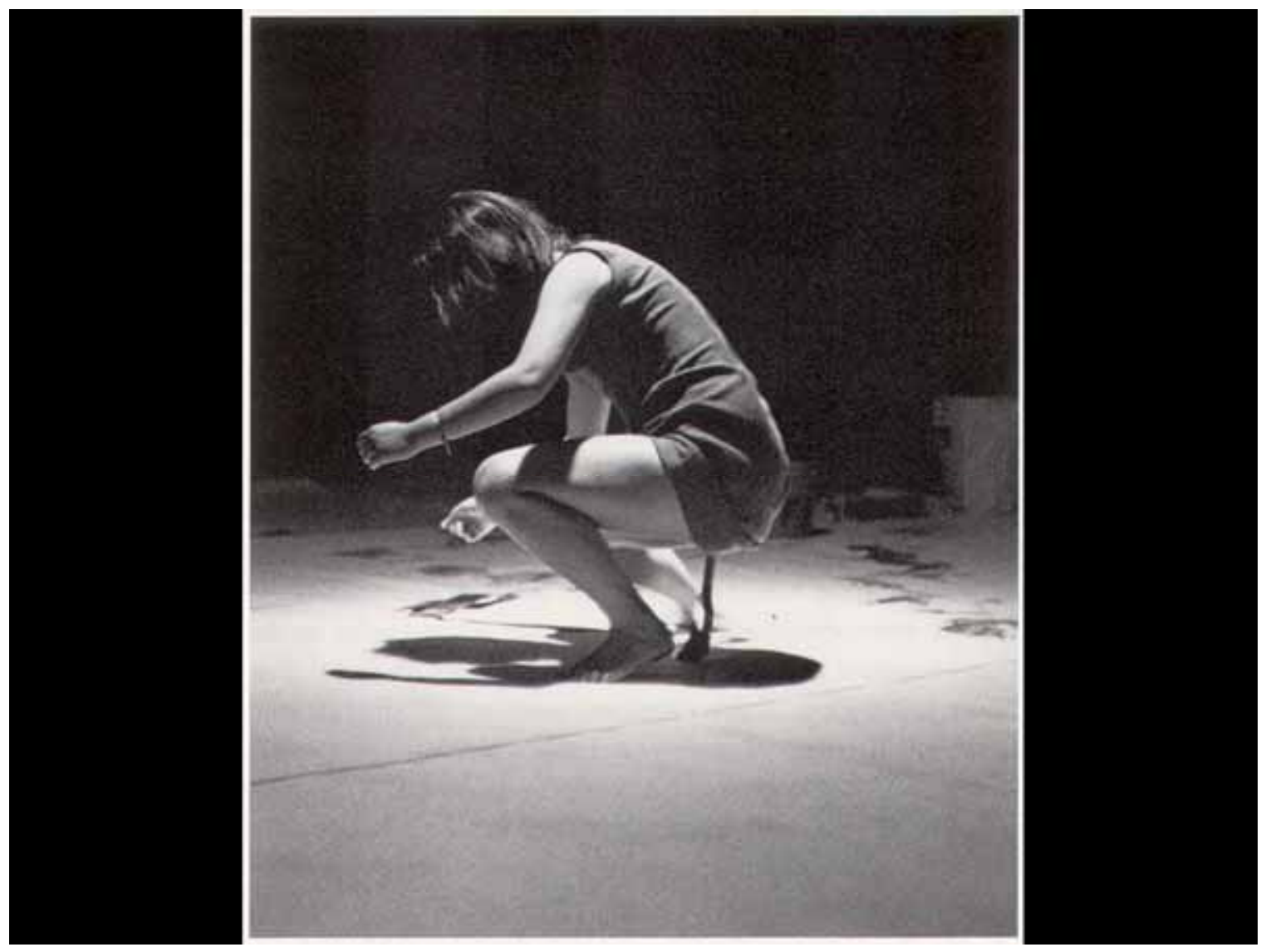




\section{Bibliography}

Barthes, Roland. Edited by Susan Sontag. A Barthes Reader. New York, NY: Hill and Wang, 1982.

Barthes, Roland. Translated by Annette Lavers. Mythologies. New York, NY: Hill and Wang, 1972.

Barthes, Roland. Translated by Richard Miller. The Pleasure of the Text. New York, NY: Hill and Wang, 1975.

Barthes, Roland. Translated by Richard Howard. The Rustle of Language. New York, NY: Hill and Wang, 1986.

Baudrillard, Jean. Translated by Charles Dudas.“Reversion of History.” L’Illusion de la fin: ou La greve des evenements. Gailee: Paris, 1992.

Available from the World Wide Web: (http://www. Simulation.dk/articles/a-reversion_of_history.html). Accessed 10/03/2003.

Berkovitch, Ellen. “Janine Antoni.” Artforum International 41 (December 2002): 142-144.

Betterton, Rosemary. An Intimate Distance: Women, Artists and the Body. New York, NY: Routledge, 1996.

Bordo, Susan. "The Body and the Reproduction of Feminity.” Writing on the Body: Female Embodiment and Feminist Theory. Edited by Katie Conboy et al. New York, NY: Columbia University Press, 1997.

Cameron, Dan. “Parts and Whole: Three Works by Janine Antoni.” Janine Antoni. New York, NY: Ink Tree Press, 2000.

Derrida, Jacques. Edited by Peggy Kamuf. A Derrida Reader: Between the Blinds. New York, NY: The Columbia University Press, 1991.

Derrida, Jacques. Translated by G. C. Spivak. Of Grammatology. Baltimore, MD: The Johns Hopkins Press, 1976.

Deitch, Jeffrey. Irrational Concepts: Nine Essays on American Artists in the Saatchi Collection. Great Britain: The Pale Green Press, 1996.

Fisher, Jennifer. "Interperformance: the live tableau of Suzanne Lacy, Janine Antoni and Marina Abramovic.” Art Journal 56 (Winter 1997): 28-33. 
Foucault, Michel. Discipline and Punish. New York, NY: Vintage, 1979.

Freud, Sigmund. Translated by James Strachey. Civilization and Its Discontents. New York: W. W. Norton \& Company, 1961.

Freud, Sigmund. Translation by Joan Riviere. A General Introduction to Psychoanalysis. Garden City, New York: Garden City Publishing Company, Inc., 1938.

Gatens, Moira. "Corporal Representation in/and the Body Politic.” Writing on the Body: Female Embodiment and Feminist Theory. Edited by Katie Conboy et al. New York, NY: Columbia University Press, 1997.

Goldberg, RoseLee. Performance: Live Art Since 1960. New York, NY: Harry N. Abrams, 1998.

Harrison, Charles and Paul Wood. Art in Theory 1900-1990: An Anthology of Ideas. Malden, MA: Blackwell Publishers Inc., 1992.

Husserl, Edmond. Tranlated by John Barnett Brough. On the Phenomenology of the Consciousness of Internal Time (1893-1917). Norwell, MA: Kluwer Academic Publishers, 1991.

Husserl, Edmond. Tranlated by R. Rojcewicz and A. Schuwer. Ideas Pertaining to a Pure Phenomenology. Norwell, MA: Kluwer Academic Publishers, 1991.

Irigaray, Luce. "The Sex Which Is Not One.” Writing on the Body: Female Embodiment and Feminist Theory. Edited by Katie Conboy et al. New York, NY: Columbia University Press, 1997.

Isaak, Jo Anna. Feminism and Contemporary Art: The Revolutionary Power of Women's Laughter. New York, NY: Routledge, 1996.

Keenan, Georgia. “Dream Weaver.” Art News 96 (September 1997): 35.

Kelly, Mary. Imaging Desire. Cambridge: The MIT Press, 1996.

Kuspit, Donald. "The Psychoanalytic Construction of Beauty.” Artnet. Available from the World Wide Web: (http://www.artnet.com/Magazine/features/kuspit/kuspit223-03asp). Accessed 10/29/03.

Lajer-Burcharth, Ewa. “Antoni’s Difference.” Janine Antoni. New York, NY: Ink Tree Press, 2000.

Levi-Straus, Claude. The Jealous Potter. Chicago: University of Chicago Press, 1996. 
Lozano, Amparo. "Presence and absence in a cyclical story by proximity.” Janine Antoni. Barcelona: La Fundacio “la Caixa,” 1996.

McEvilley, Thomas. "Marina Abramovic/ Ulay Ulay/Marina Abramovic.” Art Forum 13, no.1 (September 1983): 52.

Mulvey, Laura. "Visual Pleasure and Narrative Cinema.” Screen 16:3. (Autumn, 1975): 6-18.

Princenthal, Nancy. “Janine Antoni: Mother’s Work.” Art in America 89 (September 2001): 124-128.

Reed, Christopher. "Postmodernism and the Art of Identity.” Concepts of Modern Art: From Fauvism to Postmodernism. Edited bt Nikos Stangos. New York, NY: Thames and Hudson, 1994.

Siegal, Jeanne. "After Sherrie Levine." Art Talk: The Early 80s. Edited by Jeanne Siegal. New York, NY: Da Capo Press, 1990.

Smith, Roberta. "Conceptual Art.” Concepts of Modern Art: From Fauvism to Postmodernism. Edited bt Nikos Stangos. New York, NY: Thames and Hudson, 1994.

Taylor, Simon. “Janine Antoni at Sandra Gering.” Art in America 80 (October 1992): 149.

Van Alphen, Ernst. "The portrait’s dispersal: concepts of representation and subjectivity in contemporary portraiture.” Portraiture: Facing the Subject. Edited by Joanna Woodall. Manchester: Manchester University Press, 1997.

Weintraub, Linda. Art on the Edge and Over. Litchfield, CT: Art Insights, Inc., 1996.

Williams, Caroline. Contemporary French Philosophy: Modernity and the Persistence of the Subject. New York, NY: The Athlone Press, 2001. 